\title{
THE QUANTITATIVE AND QUALITATIVE ECONOMIC YIELD OF IRRIGATION WATER USED IN THE PRODUCTION OF SOME FIELD CROPS
}

\author{
ADEL MOHAMED ABD ELWAHAB SALEH
}

\author{
Economics Research Institute Agricultural Research Center
}

(Manuscript received 6 February 2019)

\begin{abstract}
rrigation resources are among the most important and current productive resources and the main determinant of agricultural production and expansion. Therefore, the problem of this research is determined by answering the following questions: What is the economic yield of the irrigation water used in field crops production and what is the economics of that use? The aim of this research is to determine the economic and quantitative benefits of the water unit used in the production of most field crops, in order to achieve the rationalization of irrigation water used in the production of these crops in all regions of the Republic. The results of the research were based on descriptive and quantitative analysis methods and some quantitative and value indicators for comparison between field crops average the period (2013-2017). - The amount of water discharged from Aswan to the field is about 1.25 billion cubic meters annually, representing about $10.1 \%$ of the annual average of the amount of water lost from Aswan to the field and about 12.4 billion cubic meters during the period (2003-2017). - The water balance in Egypt during the period of study took a decreasing trend from the beginning of 2003 until 2008 and then started to achieve water deficit in 2009, 2011, 2012, 2013 and 2017, and the maximum deficit in 2012 was about 4.6 billion cubic meters The lowest of about 0.2 billion cubic meters in 2017, which is due to the increase in the volume of applications on the total volume of water resources received, resulting in a deficit of about 0.11 billion cubic meters. - The Sesame crop is the first in terms of its water needs of about $5850 \mathrm{~m}^{3} /$ ton, followed by Cotton with about 5389 $\mathrm{m}^{3} /$ ton, followed by Sudanese peanut of about $2251 \mathrm{~m}^{3} / \mathrm{t}$, followed by sorghum crop with about $1734 \mathrm{~m}^{3} /$ ton. - The highest yield per cubic meter of water achieved by alfalfa was about $13.1 \mathrm{~kg} / \mathrm{m}^{3}$, followed by continuous alfalfa yield of $10.4 \mathrm{~kg} / \mathrm{m}^{3}$, then sugar beet with $8.98 \mathrm{~kg} / \mathrm{m}^{3}$, onions with $7.7 \mathrm{~kg} / \mathrm{m}^{3}$ followed by garlic and sugar cane, $4.3 \mathrm{~kg} / \mathrm{m}^{3}$.

- The efficiency of the delivery of irrigation water between the irrigated canal and the field average the period (2013-2017) at the level of the Republic reached a maximum of $93.6 \%$ for the Sesame crop, and a minimum of about $66.9 \%$ for the sugar beet crop. The efficiency of water delivery of field crops between Aswan and the field at the level of the Republic reached a maximum of about $92.6 \%$ for sugarcane crop, but only about $65.3 \%$ for maize crop. - The yield of cubic meter of field crop water for the winter meal in the different regions of the republic is higher than that of the summer crop crops, which leads to a decrease in water discharge, especially the sea side, in the middle and upper Egypt regions. - The net yield of the above water unit in the garlic crop was $6.3 \mathrm{LE} / \mathrm{m}^{3}$, followed by the onion crop at $6.2 \mathrm{LE} / \mathrm{m}^{3}$, then the continuous clover and the clover, which was 5.3, $4.1 \mathrm{LE} / \mathrm{m} 3$ respectively. - The highest yield of the cost of irrigation was achieved by the onion crop at 57.9 pounds, followed by garlic at about 39.7 pounds, lentils about 33.9 pounds, and
\end{abstract}

Abstract 
permanent clover about 33.3 pounds. - Clover yield is estimated to be the first by irrigation costs to $31.4 \%$, followed by $29.2 \%$, followed by sugarcane, rice, $(18.7 \%, 17.6 \%)$ respectively.

Sugar cane and alfalfa crops ranked first and second with irrigation costs to $11.8 \%, 11.4 \%$ respectively, followed by rice yield $11.1 \%$.- The correlation between the net yield of feddan and the net return of the water unit for some types of cropping patterns reached an average of about 0.51 .

\section{RECOMMENDATIONS}

1- Expanding the cultivation of the most efficient crops in the use of irrigation water, which achieve the highest return of irrigation water unit. 2- Reducing water losses and raising the efficiency of water transport and distribution, covering main canals and using pipes to reduce evaporation losses from water. 


\author{
المردود الإقتصادى الكمى والقيمى لمياه الرى

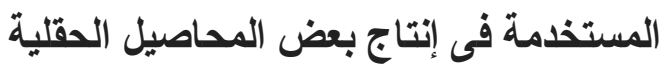 \\ عادل محمد عبد الوهاب صالح \\ معهد بحوث الإقتصاد الزراعى- مركز البحوث الزراعية
}

\begin{abstract}
الملذص
لُعد المو ارد الأرو ائية من أهم الموارد الإنتاجية الحالية و المحدد الرئيسى للإنتاج الزر اعى و التوسع فيه.

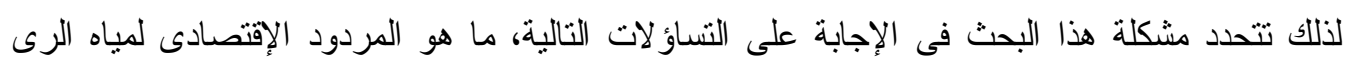

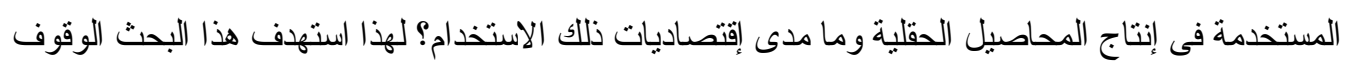
على المردود الإقتصادى كميًا وقيميًا لوحدة المياه المستخدمة فى إنتاج معظم المحاصيل الحقلية، بغية

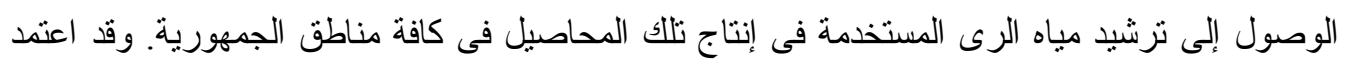
البحث فى تحقيق أهدافه على اسلوبى التحليل الوصفى و الكمى، وبعض المؤشر الته ات الكمية و القيمية للمقارنة

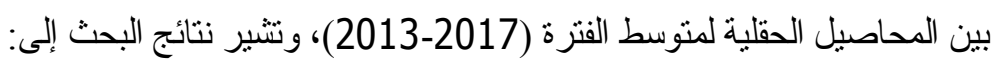

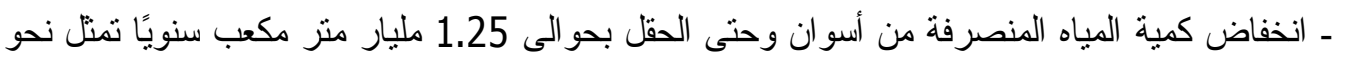

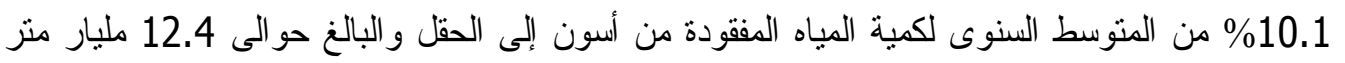

مكعب خلال فترة الدر اسة (2017-2003).

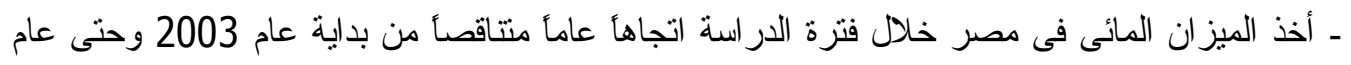

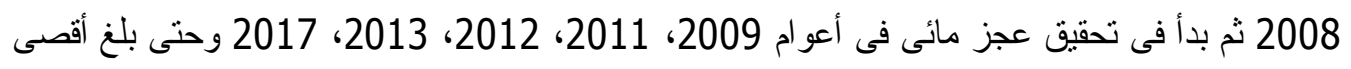

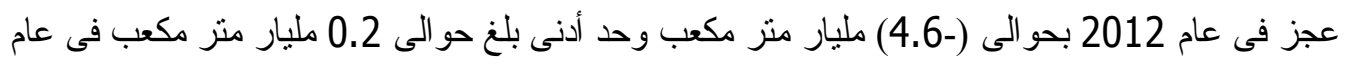

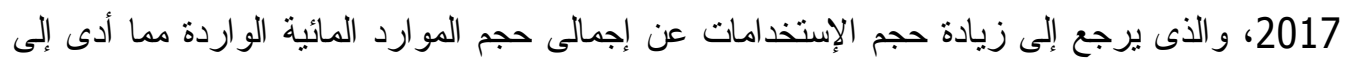

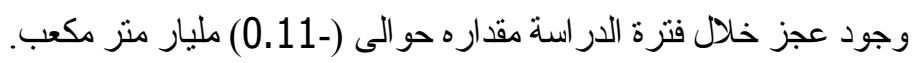
- يتصدر محصول السمسم المركز الأول من حيث احتياجاته المائية للطن لمتوسط الفترة (2017-2013) مئل

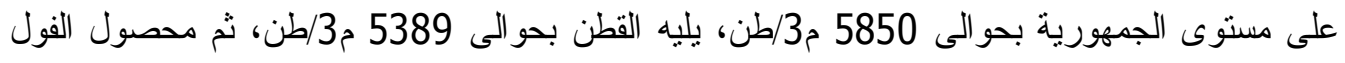

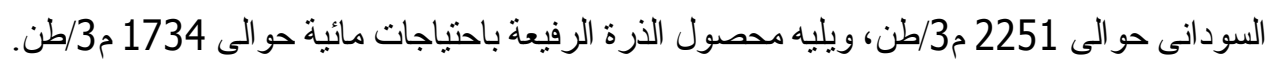

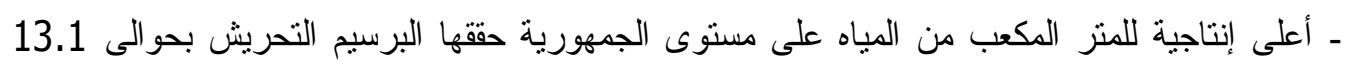

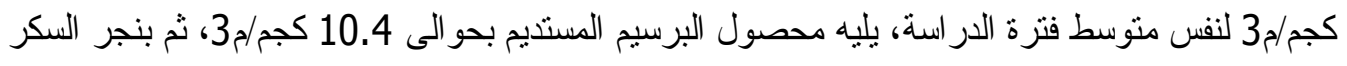

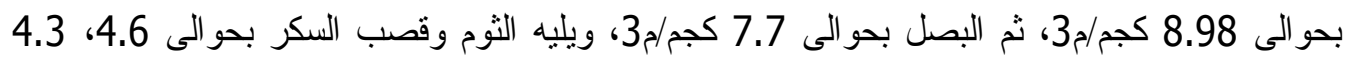
كجم/23. ـ بلغت كفاءة توصيل مياه الرى للمحاصيل الحقلية بين أفمام النزع و الحقل لمتوسط الفترة (2017-2013) على مستوى الجمهورية حدها الأقصى نحو 93.6\% لمحصول السمسم، وحدها الأدنى نحو 66.9 لمحصول بنجر السكر.

- بلغت كفاءة التوصيل المائى لنفس محاصيل الدر اسة بين أسو ان و الحقل على مستوى الجمهورية حدها

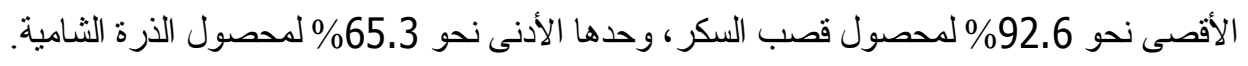
ـ عائد المتر المكعب من مياه المحاصيل الحقلية للعروة الثنتوية فى مناطق الجمهورية المختلفة يفوق نظيرة

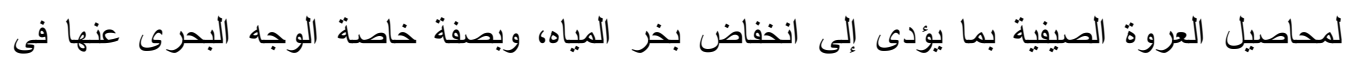
المنطقتين مصر الوسطى و العليا. 
ـ بلغ صافى عائد الوحدة المائبة على مستوى الجمهورية أعلاه في محصول الثوم بحو الى 6.3 جنبه/م3،

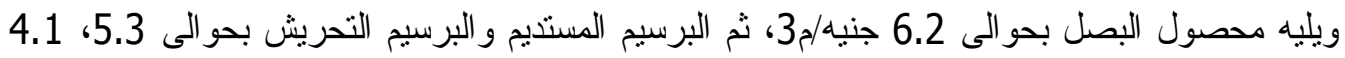
جنبه/23 على الترتيب. ـ أعلى عائد للجنيه من تكاليف الرى على مستوى الجمهورية حققه محصول البصل بحو الى 57.9 جنيه، يليه الثوم بحو اللى 39.7 جنيه، ثم العدس بحو الى 33.9 جنيه، و البرسيم المستخيم بحو الى لـ 33.3 جنيه. - يتصدر محصول البرسيم التحريش المرتبة الأولى حسب نسب دئ نكاليف الرى إلى التكاليف المتغيرة بنحو

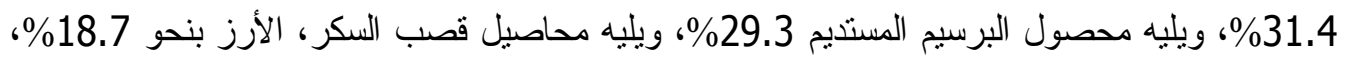
17.6\% على التزتيب. ـ يتصدر محصولى قصب السكر، البرسيم التحريش المركزين الأولى و الثانى حسب نسب تكاليف الرى إلى

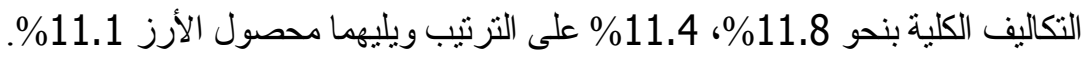
ـ قوة الأرتباط بين ترتيب صافى عائد الفدان وصافى عائد الوحدة المائية لبعض أنماط التركيب المحصول

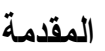

بلغت في المتوسط حو الى 0.51.

تعتبر المو ارد المائية هى المورد الطبيعى الأساسى لأى تتمية نظر أ لعلاقتها المبانثرة بأنشطة الأنسان

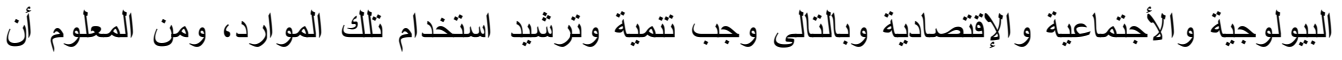

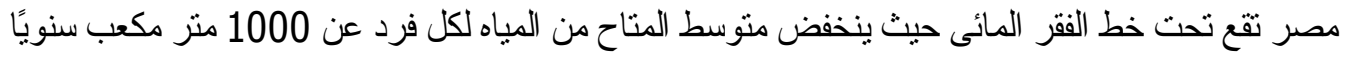

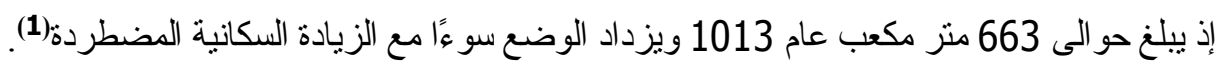

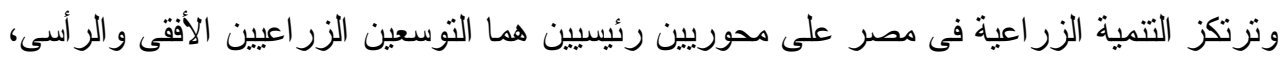

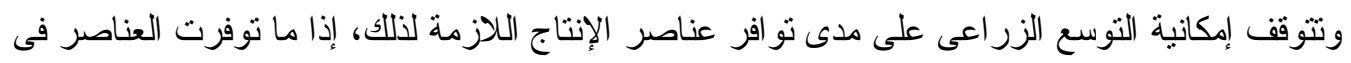

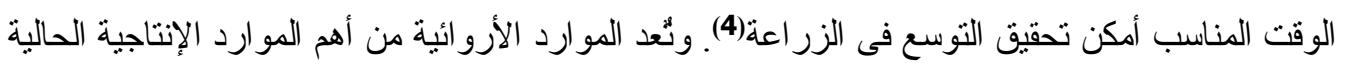

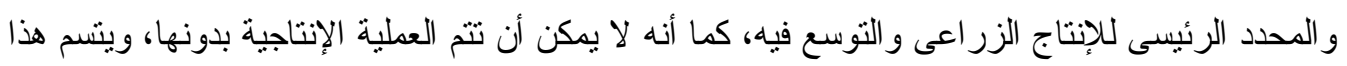

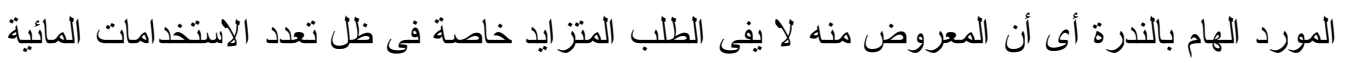

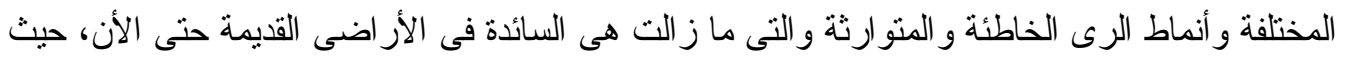

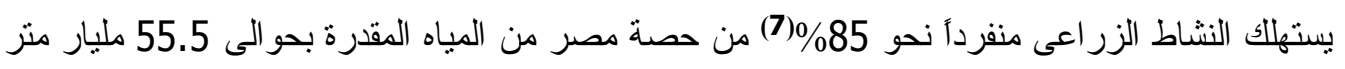

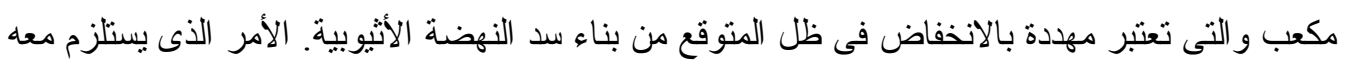

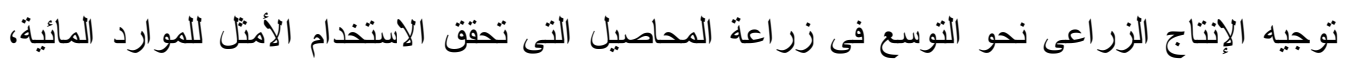

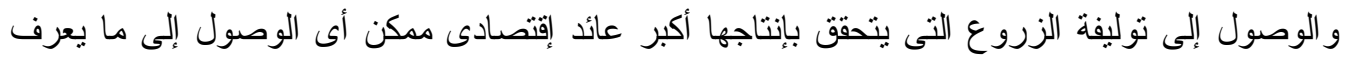

\section{مشكلة البحث}

بالتركيب المحصولى الأمنل.

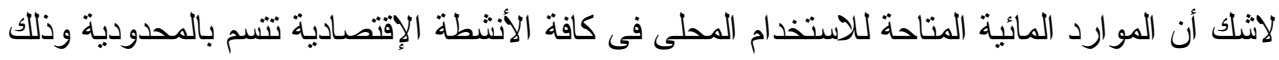

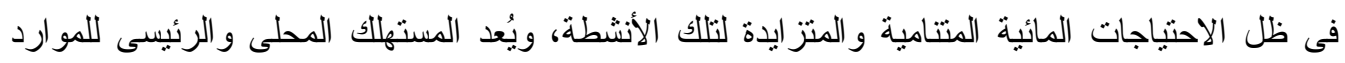

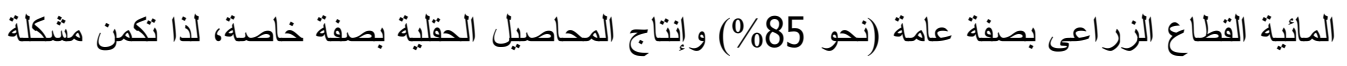

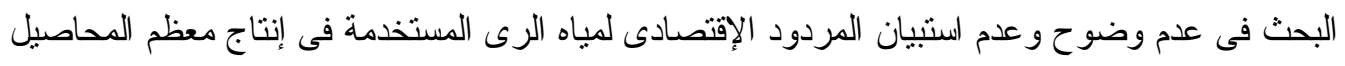

الحقلية وما مدى إقتصاديات ذلك الاستخدام؟

\section{هاف البحث}

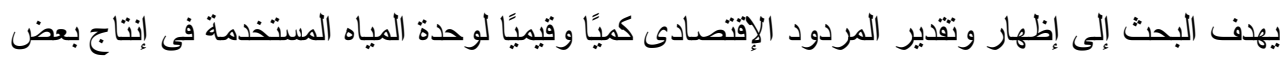

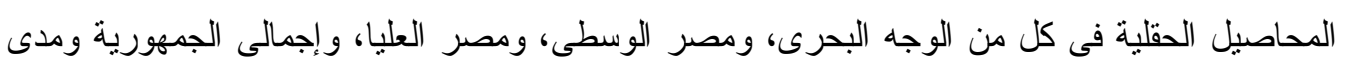


كفاءة التوصيل المائى ونسبة الفاقد على مستوى الجمهورية بهدف محاولة ترشيد مياه الرى المستخدمة فى إنتاج تلك المحاصيل فى كافة انحاء الجمهورية. الأسلوب البحثى ومصادر البيانات

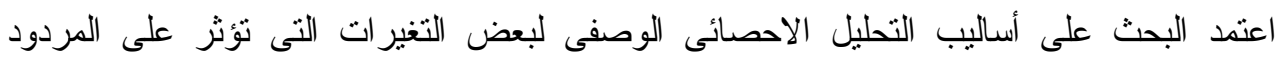

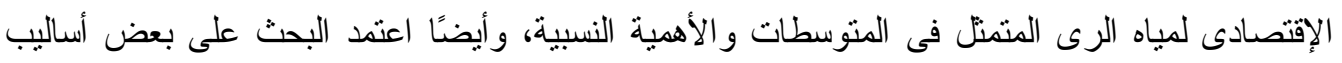

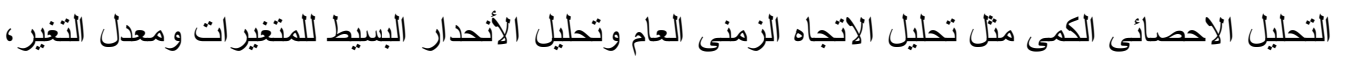

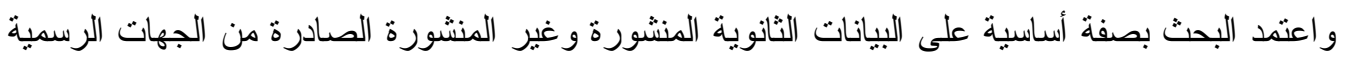
كالنشر ات و التقارير و الدر اسات المنشورة و التى يصدرها كلا من الجهاز المركزى للعبئة العامة والاحصاء،

\section{نتائج البحث}

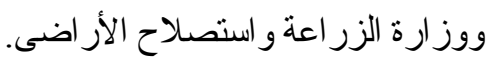

أولاً: تطور كميات مياه الرى المستخدمة وفو اقد المياه لمجموعة المحاصيل الحقلية:

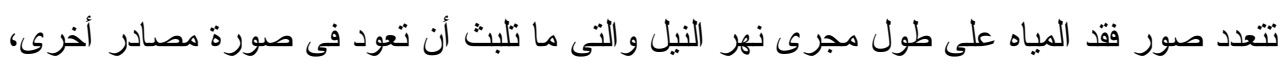

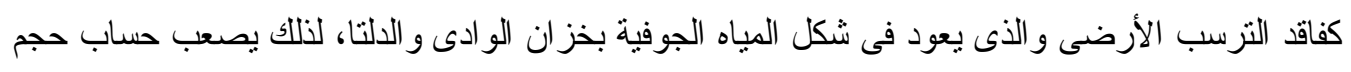

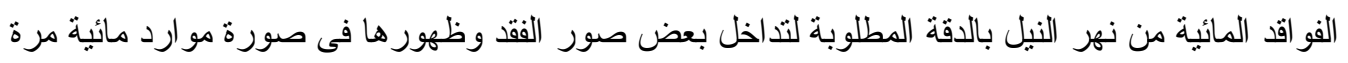
أخرى(2) ولذلك هناك نقطتين فى غاية الأهمية لابد من التعرض لهما عند دراسة المردود الإقتصادى للمو ارد

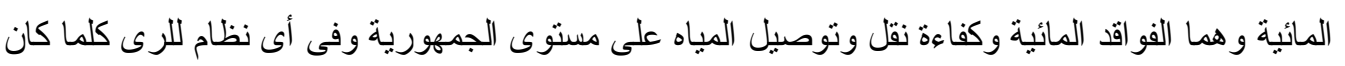

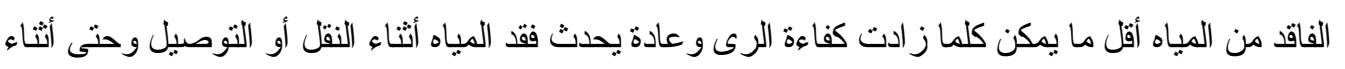

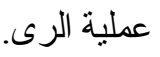

\section{1 - تطور كميات مياه الرى المستخدمة عند الحقل:}

يوضح الجدول رقم (1) أن منوسط كمية مياه الرى المنصرفة عند الحقل للمحاصيل الحقلية خلال الفترة

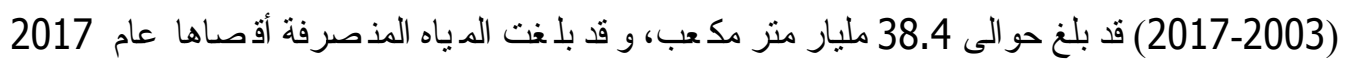

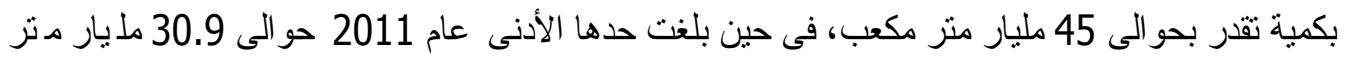

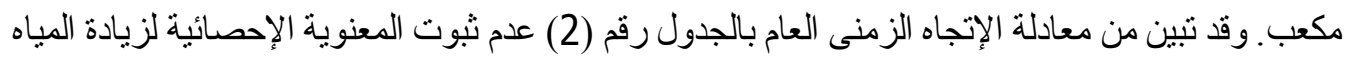

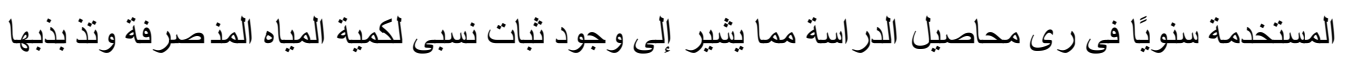

حول منوسطها السنوى خلال فترة الدر اسة. 2- تطور كميات مياه الرى المستخدمة عند أفمام الترع:

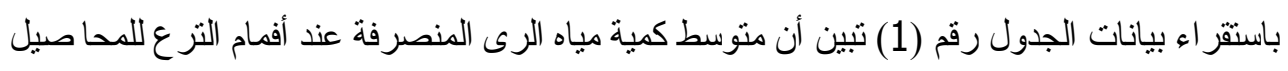

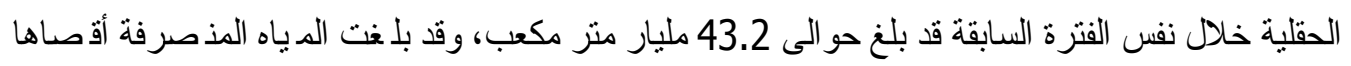

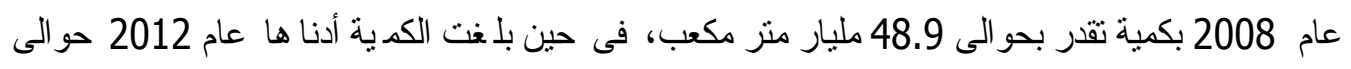

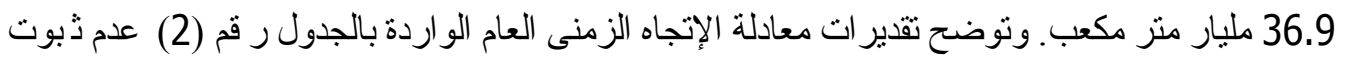

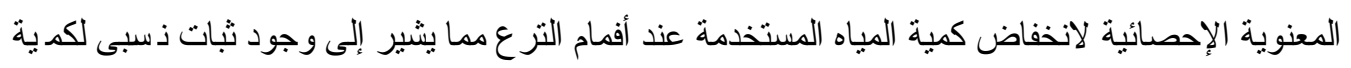

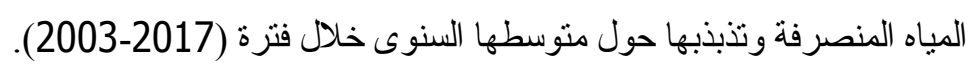
3- تطور كميات مياه الرى المستخدمة عند أسوان:

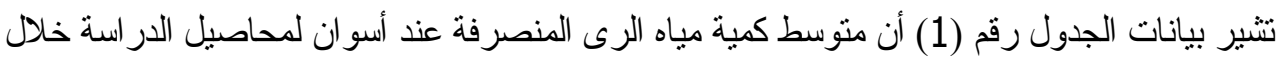
فترة الدراسة قد بلغ حو الى 50.9 مليار متر مكعب، وقد بلغت المباه المنصرفة أقصاها عام 2008 بكمية 
تقدر بحو الى 62.1 مليار منز مكعب، فى حين بلغت الكمية أدناها عام 2012 حو الى 40.1 مليار متر

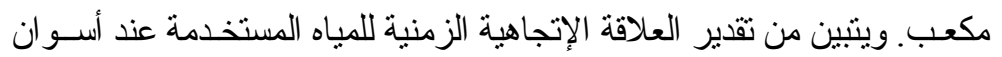
جدول رقم (1): تطور كمية مياه الرى عند أسون و أفمام الترع و الحقل وحجم الفاقد الكلى منها

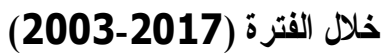

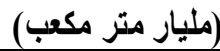

\begin{tabular}{|c|c|c|c|c|c|}
\hline \multicolumn{2}{|c|}{ الفاقد الكلى للنسرب الأرضى* } & \multicolumn{3}{|c|}{ كمبة مياه الرى المستخدمة } & \multirow[b]{2}{*}{ 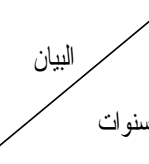 } \\
\hline$\%$ & من أسو ان إلى الحقل & عند أسو ان & عند أفمام التزع ع & داخل الحقل & \\
\hline 31.8 & 17.10 & 53.7 & 42.5 & 36.6 & 2003 \\
\hline 31.1 & 17.1 & 55 & 43.6 & 37.9 & 2004 \\
\hline 31.3 & 18 & 57.4 & 45.3 & 39.4 & 2005 \\
\hline 31.5 & 18.8 & 59.7 & 47.1 & 40.9 & 2006 \\
\hline 31.1 & 19 & 61.1 & 48.1 & 42.1 & 2007 \\
\hline 31.1 & 19.3 & 62.1 & 48.9 & $\frac{72.1}{42.8}$ & 2008 \\
\hline 30.8 & 15.4 & 50.0 & 39.2 & $\begin{array}{l}7.0 \\
34.6\end{array}$ & 2009 \\
\hline 26.2 & 13.4 & 51.2 & 42.7 & $\begin{array}{l}37.0 \\
37.8\end{array}$ & 2010 \\
\hline 28.5 & 12.3 & 43.2 & 37.0 & 30.9 & 2011 \\
\hline 20 & 8 & 40.1 & 36.9 & 32.1 & 2012 \\
\hline 17.8 & 8.2 & 46 & 43.0 & 37.8 & 2013 \\
\hline 17.8 & 8.3 & 46.6 & 43.6 & 38.3 & 2014 \\
\hline 16.7 & 7.4 & 44.2 & 41.2 & 36.8 & 2015 \\
\hline 6.4 & 3 & 46.7 & 44.5 & 43.7 & 2016 \\
\hline 2 & 0.9 & 45.9 & 44.0 & 45.0 & 2017 \\
\hline 24.4 & 12.4 & 50.9 & 43.2 & 38.4 & المتوسط السنوى \\
\hline
\end{tabular}

* هو حجم الفقد الكلى فى كمية مياه الرى عند الحقل عن كمية مياه الرى عند أسوان.

المصدر: الجهاز المركزى للتعبئة العامة والاحصاء، النشرة السنوية لاحصات الرى و الموارد المائية، أعداد مختلفة.

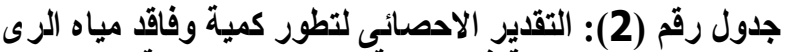

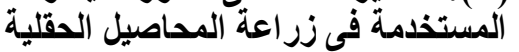

خلا الفترة (2017-2003 (20)

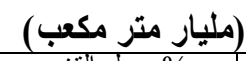

\begin{tabular}{|c|c|c|c|c|c|}
\hline \% معدل التغير & المتوسط & $2 \jmath$ & المعادلات & البيان & رقم \\
\hline - & 38.4 & 0.02 & 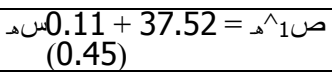 & داخل الحقل & 1 \\
\hline - & 43.2 & 0.07 & 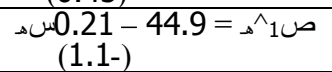 & عند أفمام الترع & 2 \\
\hline 2.2 & 50.9 & 0.53 & 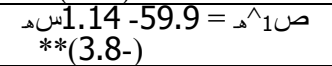 & عند أسو ان & 3 \\
\hline 10.1 & 12.4 & 0.85 & 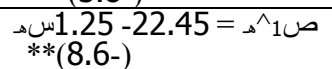 & الفاقد الكلى & 4 \\
\hline
\end{tabular}

المصدر : حسبت من جدول رقم (1).

بالجدول رقم (2) تتاقص كمية المياه المنصرفة من أسوان سنويًا بحو الى 1.14 مليار منز مكعب تمثل نحو

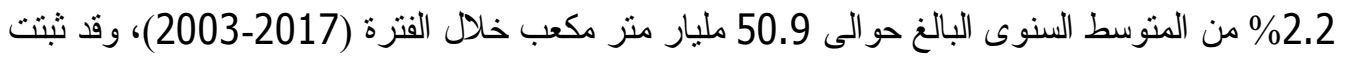

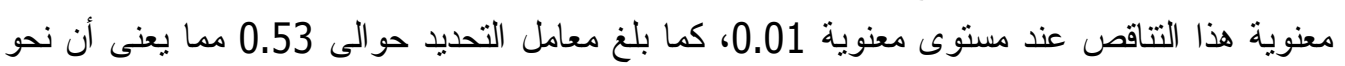
53\% من التغير ات التى طر أت على المياه المنصرفة ترجع إلى العو امل التى يعكسها الزمن. 4- نطور الفو اقد المائية من أسوان للدقل :

يتضح من بيانات الجدول رقم (1) أن كمية المياه المفقودة من أسو ان إلى الحقل تتز اوح ما ما بين حد أدنى

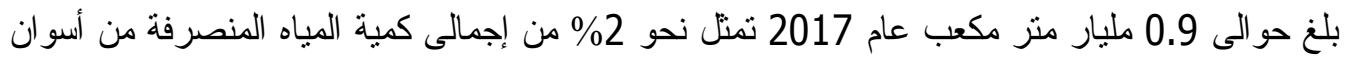

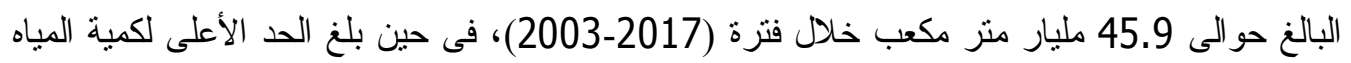


المفقودة فى هذه الفترة حو الى 19.3 مليار منز مكعب فى عام 2008 تمنل نحو 31\% من إجمالى كمية المياه البالغة حو الى 62.1 مليار متر مكعب عند أسو الفئ.

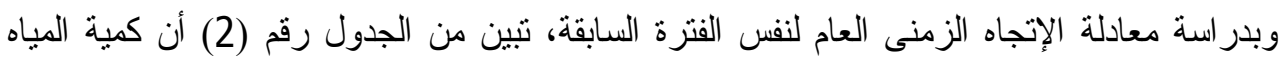

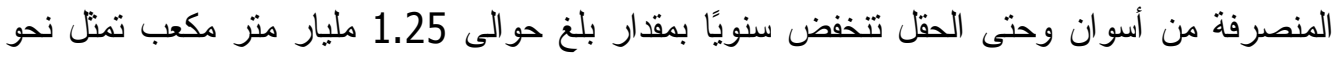
10.1\% من المتوسط السنوى البالغ حو الى 12.4 مليار منز مكعب خلال الفترة المذكورة، وقد ثبتت معنوية

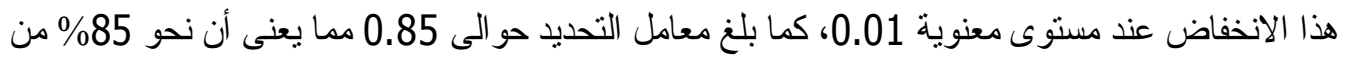

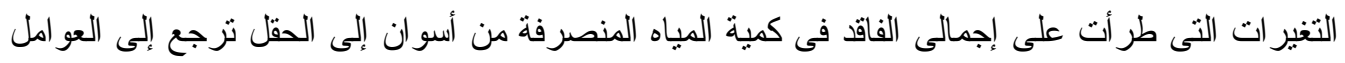

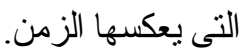
5- الوضع الر اهن للمو ارد المائية واستخدا(ماتها و الميزان المائى:

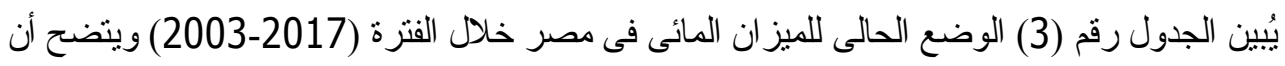

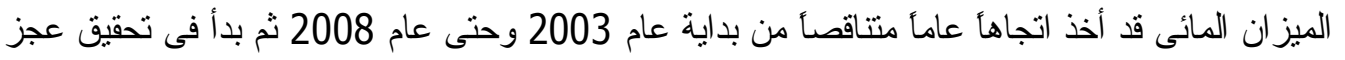
مائى فى أعو ام 2009، 2011، 2012، 2012، 2013،

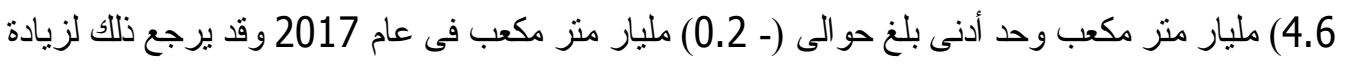

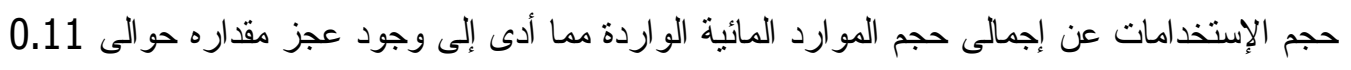
مليار متر مكعب خلال فترة الدر استة.

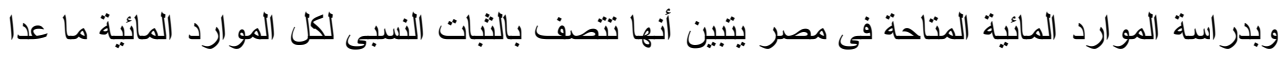

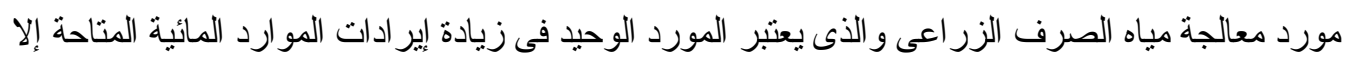

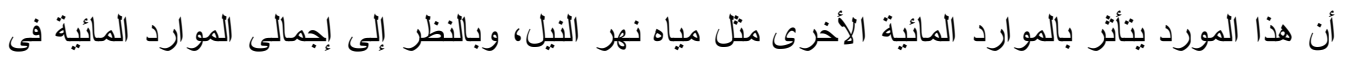

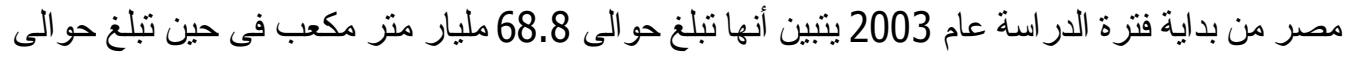

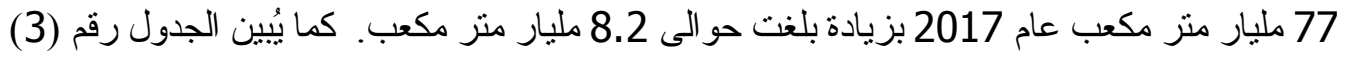

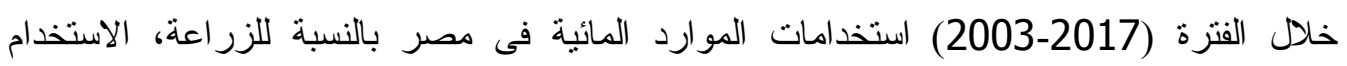

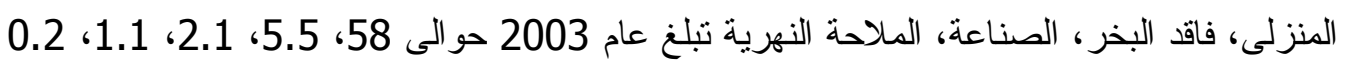

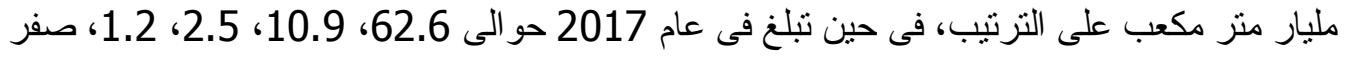

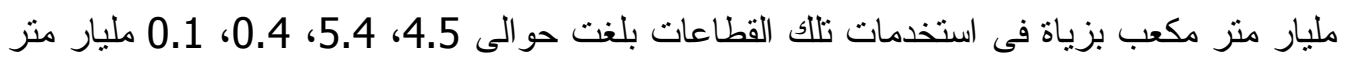
مكعب على التزتيب. يتضح مما سبق أن هناك تتاقص فى الميز ان المائى بداية من عام 2003 إلى أن تحقق أكبر عجز فى المو ارد المائية المتاحة للإستخدام يُقدر بحو الى (-4.6) مليار متر مكعب عام 2012. 
جدول رقم (3): الوضع الراهن للموارد المائية المتاحة واستخداماتها خلا الفترة (2017-2003)

(مليار متر مكعب)

\begin{tabular}{|c|c|c|c|c|c|c|c|c|c|c|c|c|c|c|}
\hline \multirow[b]{2}{*}{ المائى ان } & \multicolumn{6}{|c|}{ استخدامات الموارد المائية المتاحة } & \multicolumn{7}{|c|}{ المو ارد المائية المتاحة } & \multirow[t]{2}{*}{ 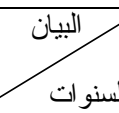 } \\
\hline & الإجمالى & النهرية الملاحة & الصناعة & البخر & المنزلى & الزر اعة & ال الإجمالى & تحلية مياه & الصحى & الزر اعى & الجوفية & المطر & النيل & \\
\hline 1.8 & 67 & 0.2 & 1.1 & 2.1 & 5.5 & 58 & 68.8 & 0.06 & 1.0 & 4.8 & 6.1 & 1.3 & 55.5 & 2003 \\
\hline 1.7 & 67.1 & 0.2 & 1.1 & 2.1 & 5.6 & 58.1 & 68.8 & 0.06 & 1.0 & 4.8 & 6.1 & 1.3 & 55.5 & 2004 \\
\hline 1.5 & 67.7 & 0.2 & 1.1 & 2.1 & 5.8 & 58.5 & 69.2 & 0.09 & 1.1 & 5.1 & 6.1 & 1.3 & 55.5 & 2005 \\
\hline 1 & 68.6 & 0.2 & 1.15 & 2.1 & 6.1 & 59 & 69.6 & 0.06 & 1.2 & 5.4 & 6.1 & 1.3 & 55.5 & 2006 \\
\hline 0.7 & 69.3 & 0.2 & 1.15 & 2.1 & 6.5 & 59.3 & 70.0 & 0.06 & 1.3 & 5.7 & 6.1 & 1.3 & 55.5 & 2007 \\
\hline 0.4 & 72.0 & 0.2 & 1.2 & 2.1 & 8.5 & 60 & 72.4 & 0.06 & 1.3 & 8 & 6.2 & 1.3 & 55.5 & 2008 \\
\hline (1.3) & 73.7 & 0.1 & 1.2 & 2.1 & 9 & 61.3 & 72.4 & 0.06 & 1.3 & 8 & 6.2 & 1.3 & 55.5 & 2009 \\
\hline 0.7 & 72.5 & 0 & 1.35 & 2.1 & 8.5 & 60.5 & 73.2 & 0.06 & 1.3 & 8.5 & 6.5 & 1.3 & 55.5 & 2010 \\
\hline (3.4) & 73.7 & 0 & 1.2 & 2.1 & 9.5 & 60.9 & 70.3 & 0.1 & 1.3 & 5.8 & 6.3 & 1.3 & 55.5 & 2011 \\
\hline$(4.6)$ & 75.5 & 0 & 1.2 & 2.5 & 9.7 & 62.1 & 70.9 & 0.1 & 1.3 & 5.2 & 7.5 & 1.3 & 55.5 & 2012 \\
\hline$(0.5)$ & 75.5 & 0 & 1.2 & 2.4 & 9.9 & 62 & 75.0 & 0.06 & 1.3 & 10.1 & 6.7 & 1.3 & 55.5 & 2013 \\
\hline 0.5 & 75.9 & 0 & 1.2 & 2.5 & 9.9 & 62.3 & 76.4 & 0.1 & 1.3 & 11.5 & 6.7 & 1.3 & 55.5 & 2014 \\
\hline 0.1 & 76.3 & 0 & 1.2 & 2.5 & 10.3 & 62.3 & 76.4 & 0.1 & 1.3 & 11.7 & 6.9 & 0.9 & 55.5 & 2015 \\
\hline 0.2 & 76.8 & 0 & 1.1 & 2.5 & 10.7 & 62.5 & 77 & 0.1 & 1.3 & 11.9 & 6.9 & 1.3 & 55.5 & 2016 \\
\hline$(0.2)$ & 77.2 & 0 & 1.2 & 2.5 & 10.9 & 62.6 & 77 & 0.1 & 1.3 & 12 & 6.8 & 1.3 & 55.5 & 2017 \\
\hline$(0.11)$ & 72.6 & 0.1 & 1.2 & 2.3 & 8.4 & 60.6 & 72.5 & 0.08 & 1.2 & 7.9 & 6.5 & 1.3 & 55.5 & المنوسط \\
\hline
\end{tabular}

1- وزارة الموارد المائية والرى، قطاع تطوير الرى، بيانات غير منشورة، المالية 2015.

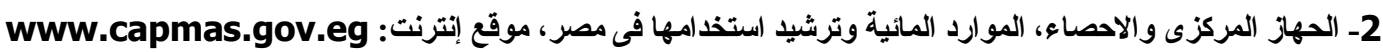


ثانياً: بعض المعايير الكمية والقيمية للمردود الإقتصادى لاستخدامات الموارد المائية:

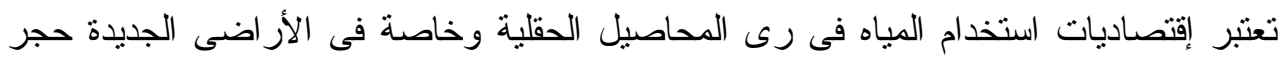

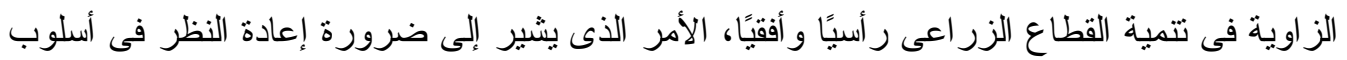

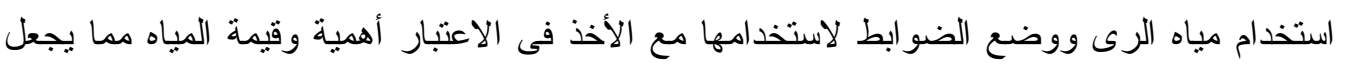

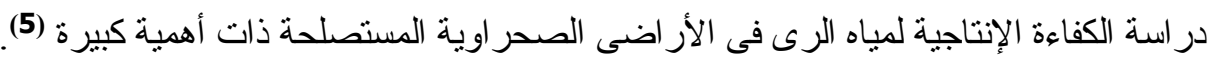
ـ بعض معايير المردود الإقتصادى الكمى لمجموعة المحاصيل الحقلية:

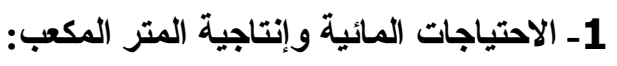

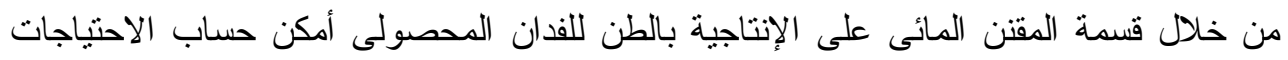

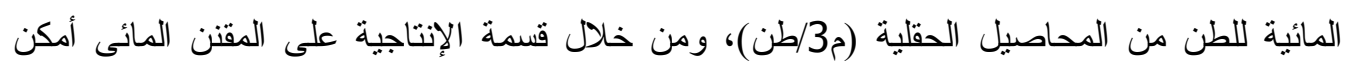

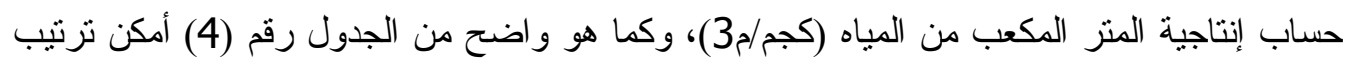

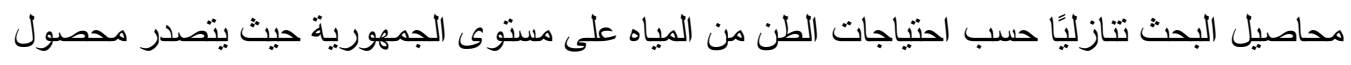

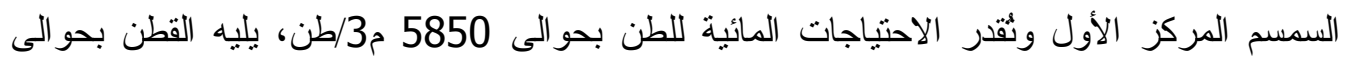

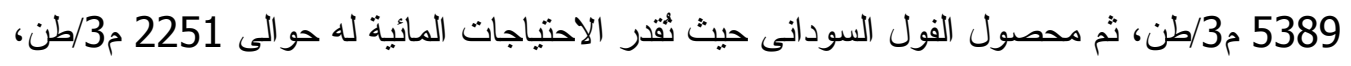

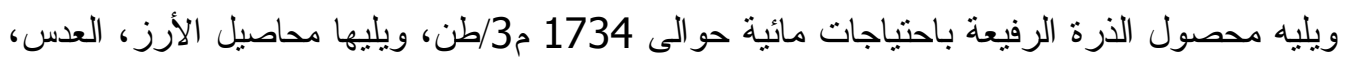

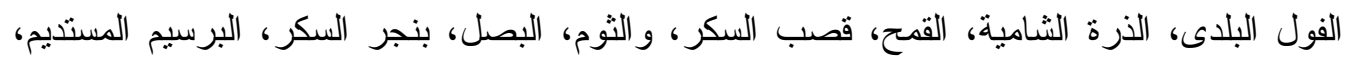

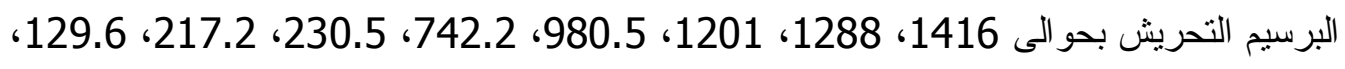

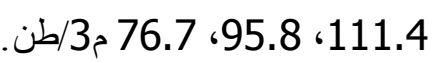

وقد جاء محصول البرسيم التحريش فى المركز الأول من حيث إنتاجية المتر المكعب من المياه على مستوى الجمهورية بحوالى 13.1 كجم/م3، يليه محصول البرسيم المستديم بحوالى 10.4

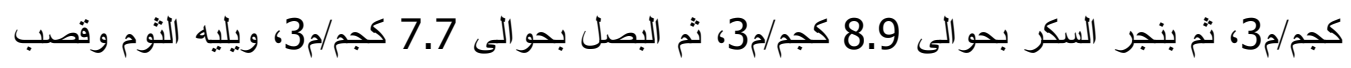

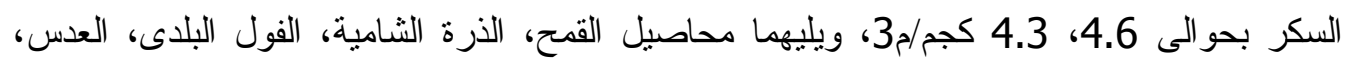

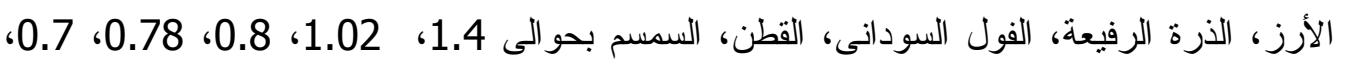

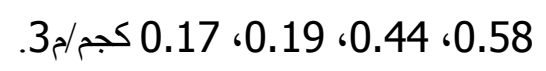
مما سبق يتبين أن أكثر محاصيل الدراسة احتياجًا لإنتاج الطن من المياه على مستوى الجمهورية

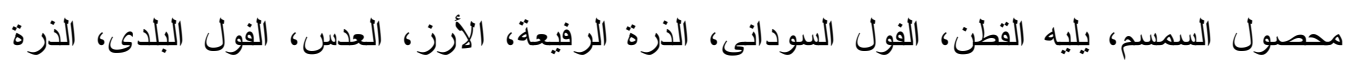

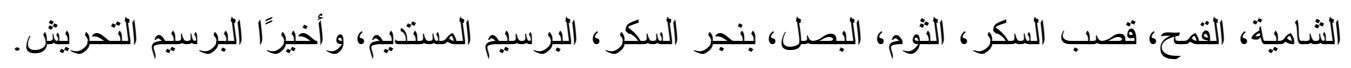

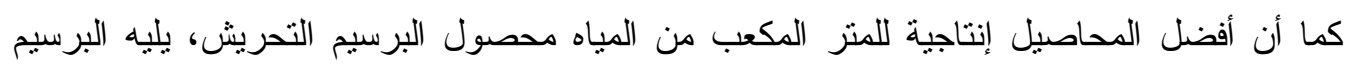

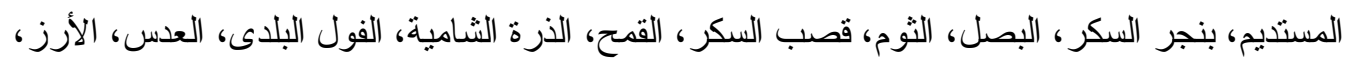

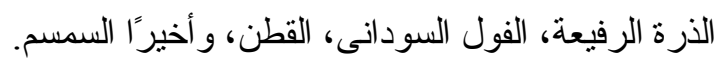


جدول (4): الاحتياجات المائية و إنتاجية المتر المكب من المياه لبعض

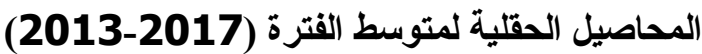

\begin{tabular}{|c|c|c|c|c|c|c|c|c|}
\hline \multicolumn{4}{|c|}{ إنتاجية المتر المكعب من المياه (كجم/م3) } & \multicolumn{4}{|c|}{ الاحتياجات المائية لإنتاج الطن (م3/طن) } & \\
\hline جمهورية & مصليا & الوسطي & بحرى وجه & جمهورية & مصري & الوسطى & بحرى وجه & \\
\hline 1.35 & 0.98 & 1.36 & 1.54 & 742.2 & 1016 & 736.7 & 649.9 & القمح \\
\hline 0.83 & 0.48 & 0.60 & 0.83 & 1201 & 2104 & 1679 & 1202 & الفول البلدى \\
\hline 0.78 & 0.55 & 0 & 0.98 & 1288 & 1834 & 0 & 1020 & 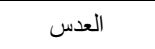 \\
\hline 7.72 & 6.54 & 6.38 & 8.38 & 129.6 & 152.9 & 156.8 & 119.3 & 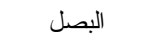 \\
\hline 4.61 & 4.02 & 4.86 & 4.03 & 217.2 & 248.9 & 205.7 & 248.2 & 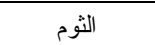 \\
\hline 10.44 & 7.44 & 8.17 & 11.7 & 95.8 & 134.5 & 122.3 & 85.6 & البرسيم المستديم \\
\hline 13.1 & 12.86 & 8.59 & 14.2 & 76.7 & 77.7 & 116.5 & 70.6 & البرسيم التحريش \\
\hline 8.98 & 8.51 & 8.92 & 9.14 & 111.4 & 117.5 & 112.1 & 109.4 & بنجر السكر \\
\hline 0.19 & 0.15 & 0.17 & 0.19 & 5389 & 6536 & 5831 & 5313 & القطن \\
\hline 0.71 & 0 & 0.59 & 0.67 & 1416 & 0 & 1686 & 1490 & الأرز \\
\hline 1.02 & 0.71 & 0.95 & 1.16 & 980.4 & 1405 & 1053 & 863.8 & الذرة الشامية \\
\hline 4.34 & 4.25 & 4.87 & 4.86 & 230.5 & 235.5 & 205.2 & 205.6 & قصب السكر \\
\hline 0.58 & 0.55 & 0.60 & 0 & 1734 & 1812 & 1658 & 0 & الذرة الرفيعة \\
\hline 0.44 & 0.35 & 0.42 & 0.49 & 2251 & 2891 & 2395 & 2031 & الفول السودانى \\
\hline 0.17 & 0.14 & 0.18 & 0.17 & 5850 & 6927 & 5697 & 5751 & السمسم \\
\hline
\end{tabular}

المصدر: جمعت وحسبت من بيانات الجدول رقم (1)، (2) بالملحق.

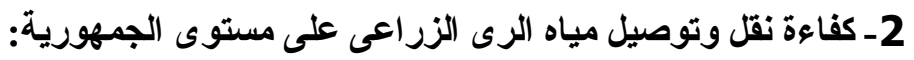

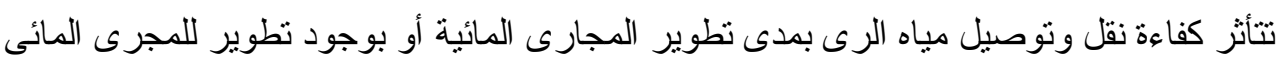
من عدمه وهى النسبة المئوية بين كمية المياه المستخدمة فى الحقل إلى كمية المياه المستخدمة عند

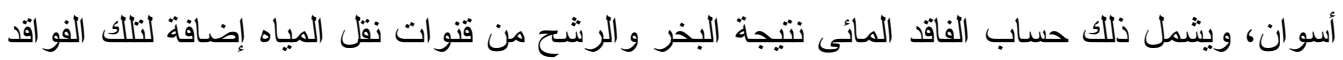

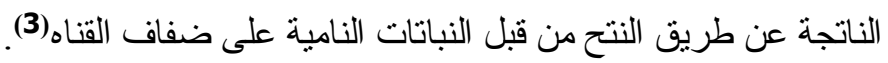
أـ كفاءة التوصيل المائى بين أسوان وعند الحقل ونسبة الفاقد وفقَا لمناطق الجمهورية: يشير الجدول رقم (5) إلى كفاءة التوصيل المائى لمناطق الجمهورية ونسبة الفو اقد فى كل منطقة لمتوسط الفترة (2017-2013) ومنه يتضح أن كفاءة توصيل مياه الرى منخفضة ـ للفترة المذكورة حيث تبلغ أدناها نحو 79.3\%، ممثله لمنطقة الوجه البحرى، تليها منطقة مصر الوسطى نحو

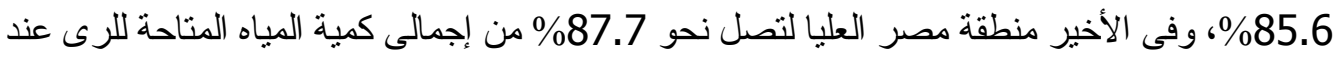

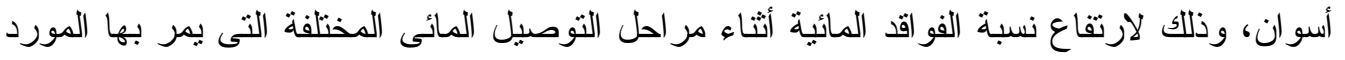

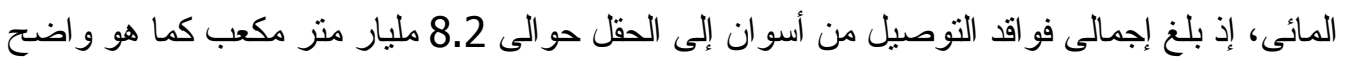

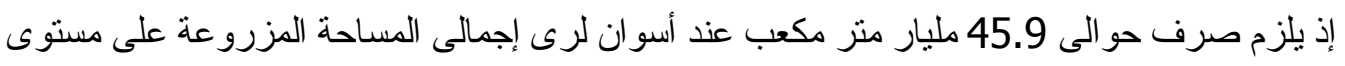

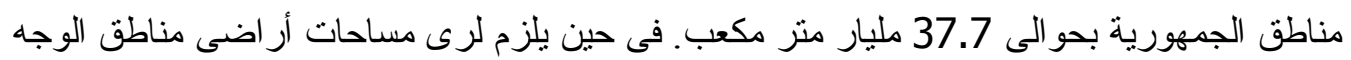

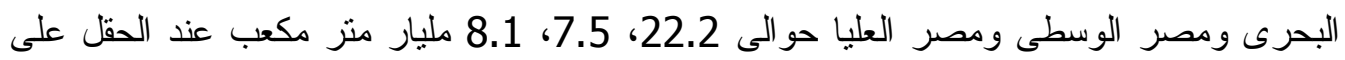

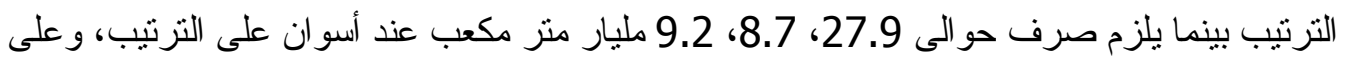

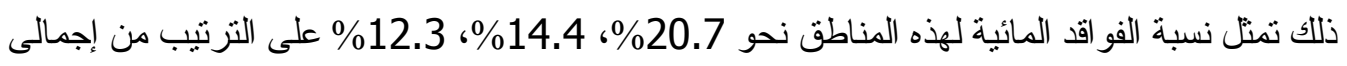

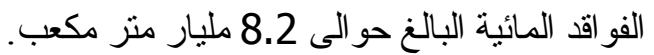




\section{جدول رقم (5): كفاعة التوصيل المائى لمناطق الجمهورية ونسبة}

الفو اقد فى كل منطقة لمتوسط القترة (5) (2013-2017)

(مليون مثر مكعب)

\begin{tabular}{|c|c|c|c|c|c|}
\hline منطبة الفو اقدة لكل & لكل منطقة الفية & 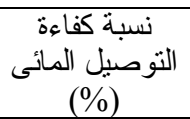 & المستخدمة عند أسياه & المستخدمة المباهد & البس \\
\hline 20.7 & 5776 & 79.3 & 27949 & 22173 & الوجه البحرى \\
\hline 14.4 & 1252 & 85.6 & 8723 & 7471 & مصر الوسطى \\
\hline 12.3 & 1133 & 87.7 & 9208 & 8075 & مصر العليا \\
\hline 17.8 & 8161 & 82.2 & 45880 & 37719 & الجمهورية \\
\hline
\end{tabular}

المصدر: الجهاز المركزى للتعبئة العامة والاحصاء، النشرة السنوية لاحصات الرى والموارد المائية، أعداد مختلفة.

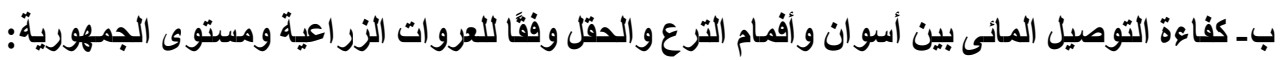

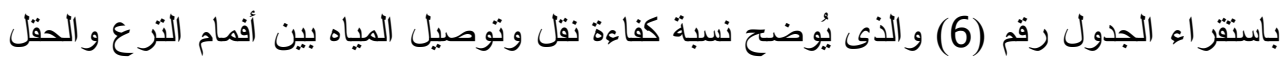
على مستوى العروات الزر اعية ومنه يتضح أن الحد الأقصى بلغ نحو 97.9\% لمحاصيل الفاكهة فى بـ مصر الوسطى وحد أدنى ييلغ نحو 85.9\% للعروة الثنتية فى الوجه البحرى. كما تتزاوح كفاءة التوزيع بين أسوان و الحقل بين الحد الأقصى البالغ نحو 91.8\% لمحاصيل الفاكهة فى مصر الوسطى

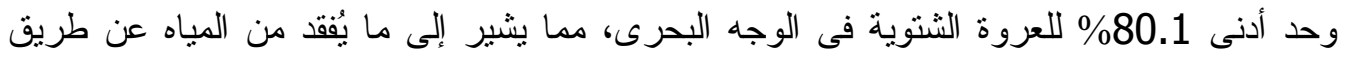
التسرب و الرشح العميق و الفاقد السطحى بالبخر . جدول رقم (6): كفاءة التوصيل المائى بين أسوان و أفمام الترع والحقل ونسبة الفاقد الكلى على لفئ

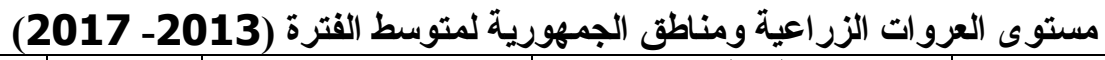

\begin{tabular}{|c|c|c|c|c|c|c|c|}
\hline \multirow{2}{*}{ نسبة الفو اقد } & \multirow{2}{*}{ وحنى السو انلى الفقل } & \multicolumn{2}{|c|}{ نسبة كفاءة التوصيل المائى * (\%) } & \multicolumn{3}{|c|}{ كمينة المياه المستخدمة متبون } & \multirow{2}{*}{ و العزووات } \\
\hline & & بين أسو ان & بين أفمام التزر ع & 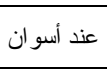 & 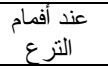 & عند الحقل & \\
\hline 19.9 & 1678 & 80.1 & 85.9 & 8421 & 7849.6 & 6744 & العروة الثنتوى \\
\hline 15.7 & 2445 & 84.3 & 90.3 & 15547 & 14507 & 13102 & العروة الصيفى \\
\hline 12.4 & 68.2 & 87.6 & 94.6 & 549 & 508.2 & 480.8 & العروة النيلى \\
\hline 18.7 & 425.8 & 81.3 & 87.9 & 2272 & 2099.8 & 1847 & محاصيل الفاكهة \\
\hline 17.2 & 4617 & 82.8 & 88.8 & 26790 & 24964 & 22173 & منطقة الوجه البحرى \\
\hline 14.7 & 441.4 & 85.3 & 92.3 & 2998 & 2769 & 2556 & العروة الشتوى \\
\hline 15.6 & 678.4 & 84.4 & 90.4 & 4350 & 4063 & 3671 & العروة الصيفى \\
\hline 13.3 & 90.6 & 86.7 & 93.6 & 680.4 & 630.2 & 589.8 & العروة النيلى \\
\hline 8.2 & 57.2 & 91.8 & 97.7 & 695.6 & 653.6 & 638.4 & محاصيل الفاكهة \\
\hline 14.5 & 1268 & 85.5 & 91.9 & 8723 & 8115 & 7456 & منطقة مصر الوسطى \\
\hline 9.6 & 221.4 & 90.4 & 94.7 & 2304 & 2199 & 2082 & العروة الثنوى \\
\hline 13.1 & 812.6 & 86.9 & 91.1 & 6215 & 5930 & 5402 & العروة الصيفى \\
\hline 13.9 & 20 & 86.1 & 91.4 & 143.8 & 135.4 & 123.8 & العروة النبلى \\
\hline 14.5 & 79 & 85.5 & 90.3 & 545.6 & 516.6 & 466.6 & محاصيل الفاكهة \\
\hline 12.3 & 1133 & 87.7 & 92 & 9208 & 8780 & 8075 & منطقة مصر العليا \\
\hline 17.1 & 2341 & 82.9 & 88.8 & 13723 & 12817 & 11382 & العروة الشتوى \\
\hline 15.1 & 3937 & 84.9 & 90.5 & 26112 & 24499 & 22175 & العروة الصيفى \\
\hline 13 & 178.8 & 86.9 & 93.8 & 1373 & 1274 & 1194 & العروة النيلى \\
\hline 16 & 562 & 84 & 90.3 & 3514 & 3270 & 2952 & محاصيل الفاكهة \\
\hline 15.7 & 7019 & 84.3 & 90.1 & 44722 & 41860 & 37703 & إجمالى الجمهورية \\
\hline
\end{tabular}

* كفاعة التوصيل المائى= (كمية المياه الو اصلة للحقل ب كمية المياه المُنطلة من مصدر الرى) × 100 المصدر: الجهاز المركزى للتعبئة العامة والاحصاء، النشرة السنوية لاحصات الرى و الموارد المائية، أعداد مختلفة.

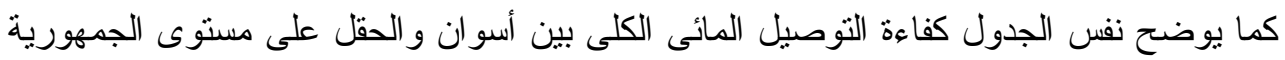
كمتوسط للفترة (2017-2013) حيث بلغت نحو 84.3\% من كمية المياه المستخدمة عند أسوان، فى لئ 
حين بلغت كميات المياه المستخدمة عند أسوان حو الى 44.7 مليار متر مكعب فى حين ما يصل إلى

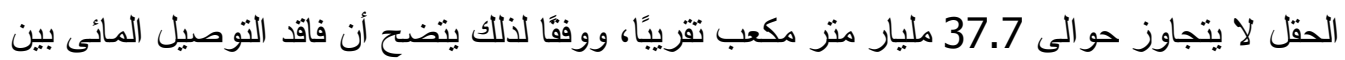

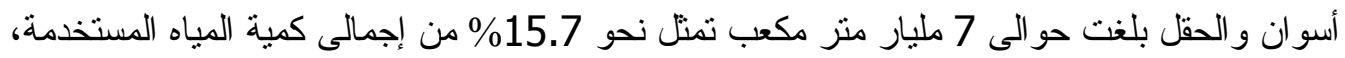

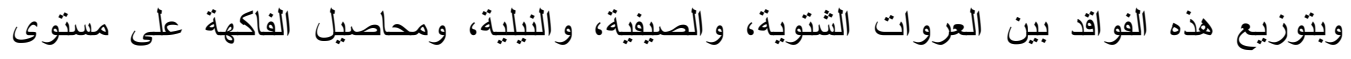

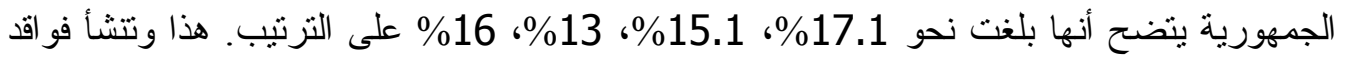

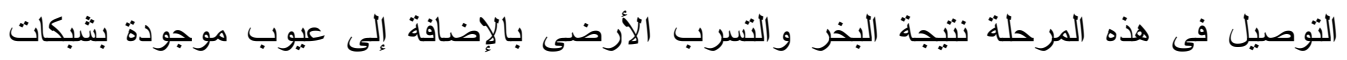

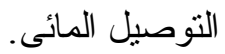
جـ كفاعة التوصيل المائى من أسوان إلى الحقل للمحاصيل الحقلية وفقًا لمستوى مناطق الجمهورية:

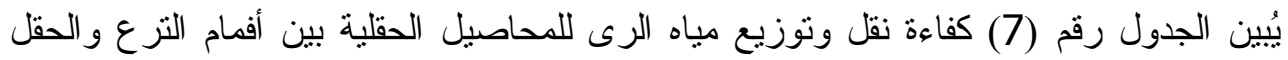
لمتوسط الفترة (2017-2013) على مستوى الوجه البحرى تقع بين حدين الأقصى ويبلغ نحو

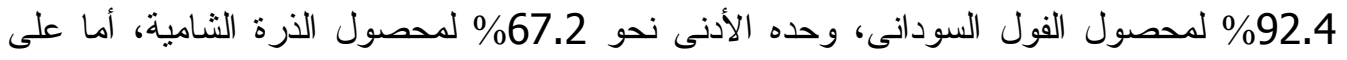

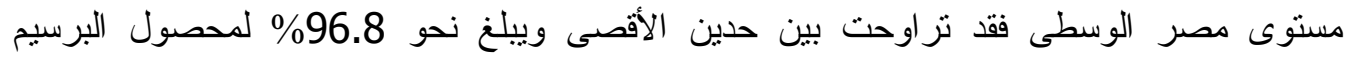

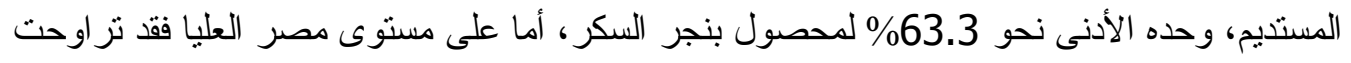

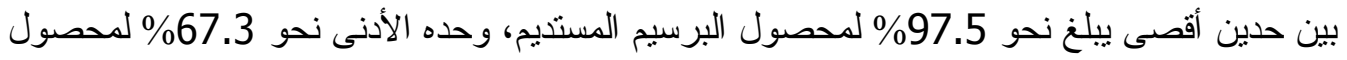

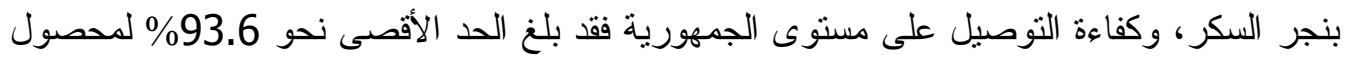

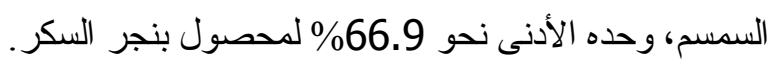

جدول رقم (7): كفاعة النقل والتوصيل المائى من أسوان إلى الحقل لبعض المحاصيل الحقلية على

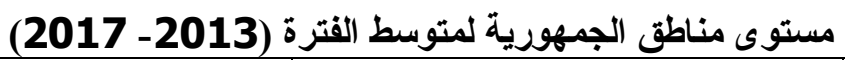

\begin{tabular}{|c|c|c|c|c|c|c|c|c|}
\hline \multicolumn{4}{|c|}{ نسبة كفاءة التوصيل بين أسو ان و الحقل (\%) } & \multicolumn{4}{|c|}{ نسبة كفاءة التوصيل بين أفمام التز ع و الحقل (\%) } & \\
\hline الجمهورية & العصليا & مصرى & بحرى & الجمهورية & مصل & الوسطى & بحرى وجه & \\
\hline 83.2 & 90.2 & 85.3 & 79.8 & 89.5 & 94.4 & 91.4 & 86.8 & 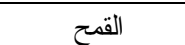 \\
\hline 82.6 & 85 & 83.7 & 82 & 89.2 & 89 & 89.8 & 89.3 & 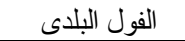 \\
\hline 68.9 & 79.5 & 0.0 & 63.5 & 74.4 & 83.4 & 0.0 & 69.6 & 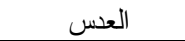 \\
\hline 77.4 & 81.6 & 79.1 & 76.2 & 83.6 & 86.3 & 84.3 & 82.9 & البصل \\
\hline 78.6 & 81.4 & 78.7 & 76.2 & 83.8 & 85.1 & 83.9 & 82.9 & الثوم \\
\hline 85.7 & 92.9 & 90.2 & 82.3 & 92.4 & 97.5 & 96.8 & 89.5 & البرسيم المستديم \\
\hline 67.9 & 71.1 & 68 & 67.6 & 73.5 & 73.9 & 72.2 & 73.8 & البرسيم التحريش \\
\hline 62.2 & 70 & 58 & 63.2 & 66.9 & 67.3 & 63.3 & 67.9 & بنجر السكر \\
\hline 83.5 & 83.1 & 80 & 83.9 & 90.2 & 86.8 & 87.2 & 90.6 & 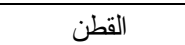 \\
\hline 86 & 0.0 & 77.2 & 75.2 & 91.3 & 0 & 80.3 & 79.8 & الأرز \\
\hline 65.3 & 74.7 & 63.4 & 61.6 & 71.0 & 78.2 & 70.6 & 67.2 & الذرة الثامبة \\
\hline 92.6 & 93.7 & 85.1 & 81.2 & 91.4 & 91.4 & 90.9 & 88.2 & قصب السكر \\
\hline 85.5 & 86.3 & 84.1 & 0 & 90.3 & 90.4 & 90 & 0.0 & الذرة الرفيعة \\
\hline 85.7 & 86.7 & 87.8 & 84.9 & 92.7 & 91.5 & 94.1 & 92.4 & الفول السودانى \\
\hline 87 & 87.6 & 80.1 & 84.3 & 93.6 & 92.1 & 85.8 & 91.7 & السمسم \\
\hline
\end{tabular}

المصدر: الجهاز المركزى للتعبئة العامة والاحصاء، النثرة السنوية لاحصات الرى و الموارد المائية، أعداد مختلفة.

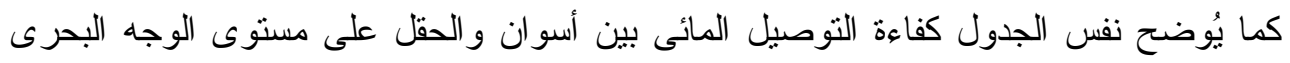

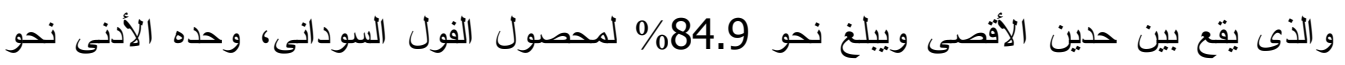

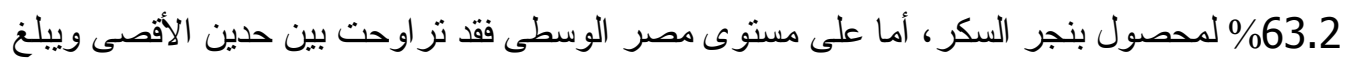

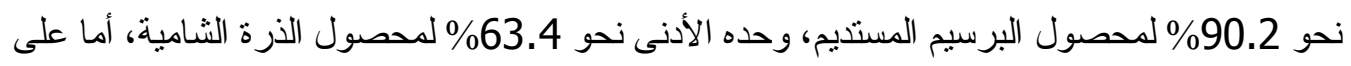

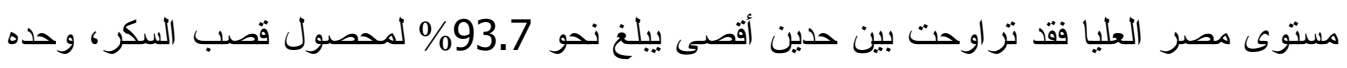


الأدنى يبلغ نحو 70\% لمحصول بنجر السكر، و على مستوى الجمهورية فقد بلغ الحد الأقصى نحو

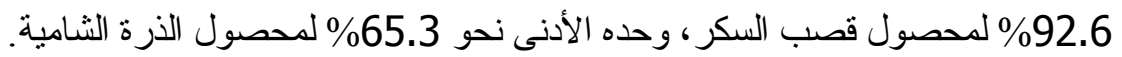

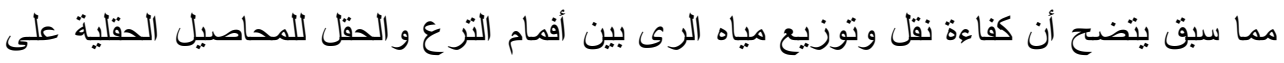

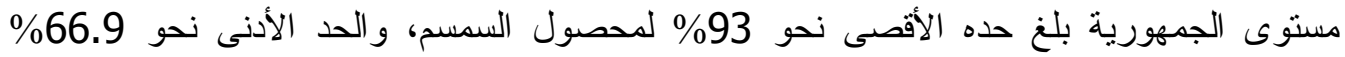

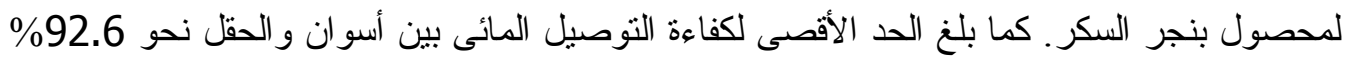

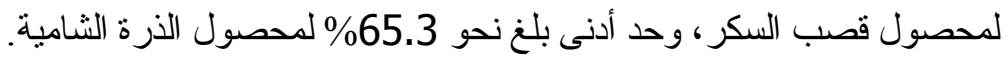
- بعض معايير المردود الإقتصادى القيمى لمجموعة المحاصيل الحقلية: 1 - عائد المتر المكعب من مياه الرى: بالنسبة لعائد المتز المكعب للمحاصيل الحقلية على مستوى الجمهورية كما هو و اضح بالجدول رقم (8) لمنوسط الفترة (2017-2013) يتضح أن صافى عائد المتز المكعب من مياه محاصيل العروة الشتوية فى مناطق الجمهورية المختلفة يفوق نظيرة لمحاصيل العروة الصيفية، ويرجع ذللك بطبيعة الحال إلى إنخفاض المقنن المائى وكمية المياه المخصصة لتلك المحاصيل نتيجة إنخفاض درجات الحرارة فى فصل الثتاء عنها فى فصل الصيف، بما يؤدى إلى انخفاض بخر المياه، وبصفة خاصة

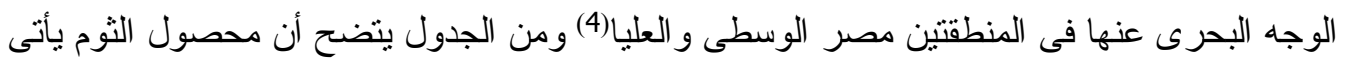

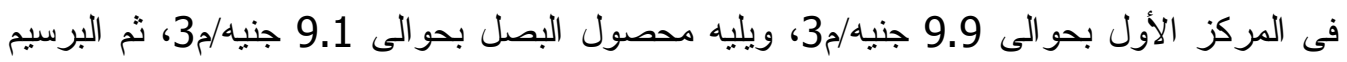
المستديم و العدس بحوالى 8.5، 7.2 جنيه/م3 على الترتيب، ويليهما البرسيم المستديم، القمح، الفول

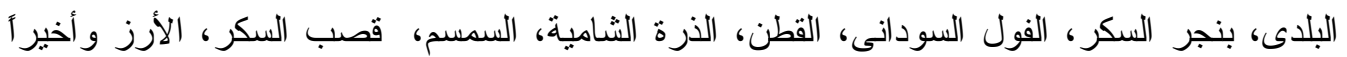

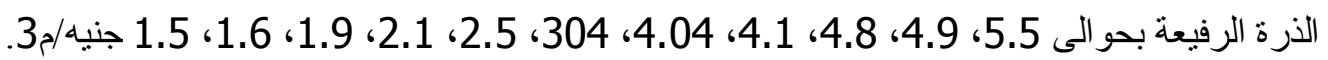

\section{جدول (8): صافى عائد الوحدة المائية لبعض المحاصيل}

\section{الحقلية لمتوسط الفترة (2013-2013)}

\begin{tabular}{|c|c|c|c|c|c|c|c|c|c|c|}
\hline \multirow{2}{*}{ (جنيه/فداني العائد } & \multirow{2}{*}{ الإير اد الكلى } & \multicolumn{4}{|c|}{ صافى عائد المتر المكعب من المياه * 3) } & \multicolumn{4}{|c|}{ عائد المتر المكعبدمن من المياه * } & \multirow[t]{2}{*}{ /البيان } \\
\hline & & جمهورية & 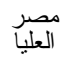 & 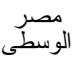 & بحرى - مجه & جمهورية & مالعليا & 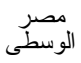 & 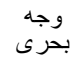 & \\
\hline 3732 & 10082 & 1.80 & 1.34 & 1.76 & 2.01 & 4.86 & 3.62 & 4.76 & 5.44 & القمح \\
\hline 2112 & 8387 & 1.21 & 0.84 & 1.13 & 1.29 & 4.82 & 3.33 & 4.50 & 5.14 & البلاى \\
\hline 2605 & 7992 & 2.36 & 1.84 & 2.31 & 2.72 & 7.23 & 5.65 & 7.08 & 8.34 & العدس \\
\hline 11895 & 17569 & 6.17 & 4.54 & 5.92 & 6.58 & 9.11 & 6.71 & 8.74 & 9.71 & البصل \\
\hline 12644 & 20037 & 6.26 & 4.83 & 6.29 & 6.99 & 9.92 & 7.65 & 9.96 & 11.08 & الثُوم \\
\hline 11804 & 16031 & 4.1 & 2.90 & 3.80 & 4.52 & 5.53 & 3.94 & 5.16 & 6.14 & البرستيم \\
\hline 5008 & 8015.6 & 5.3 & 3.86 & 4.41 & 5.69 & 8.49 & 6.17 & 7.05 & 9.10 & 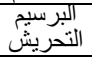 \\
\hline 3915 & 9679.8 & 1.66 & 1.13 & 1.48 & 1.73 & 4.10 & 2.80 & 3.66 & 4.28 & ألنكر \\
\hline 6212 & 12411 & 1.52 & 1.10 & 1.35 & 1.54 & 3.04 & 2.20 & 2.70 & 3.08 & القطن \\
\hline 3071 & 8892 & 0.55 & 0 & 0.50 & 0.55 & 1.59 & 0 & 1.45 & 1.59 & الارز \\
\hline 2456 & 7848 & 0.77 & 0.62 & 0.76 & 0.80 & 2.45 & 1.97 & 2.42 & 2.57 & 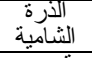 \\
\hline 11273 & 21345 & 1.02 & 0.99 & 1.25 & 1.49 & 1.93 & 1.87 & 2.36 & 2.82 & أسكرب \\
\hline 1741.5 & 5534 & 0.46 & 0.43 & 0.53 & 0.57 & 1.47 & 1.36 & 1.68 & 1.80 & الز الذرة \\
\hline 7179.8 & 12789 & 2.27 & 1.72 & 2.11 & 2.41 & 4.04 & 3.06 & 3.75 & 4.30 & السودانى \\
\hline 3140.5 & 7041 & 0.94 & 0.75 & 0.92 & 1.05 & 2.11 & 1.67 & 2.05 & 2.34 & السمسم. \\
\hline
\end{tabular}

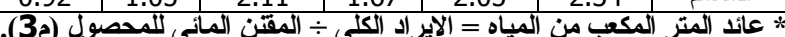

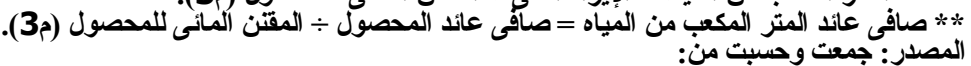

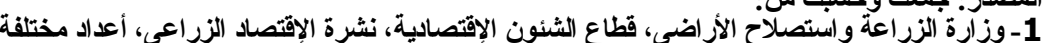

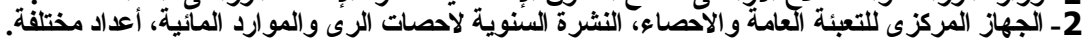


2- صافى عائد المتر المكب من مياه الرى:

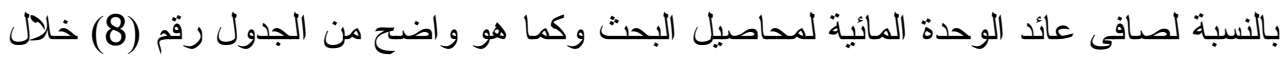

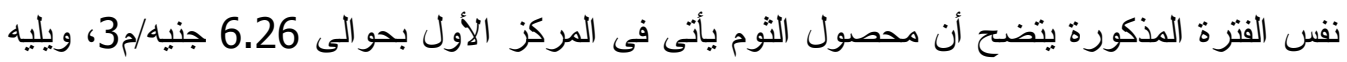

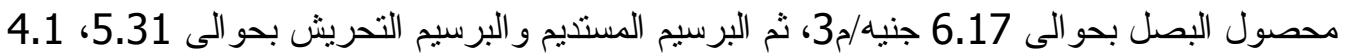

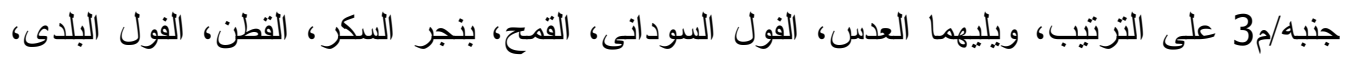

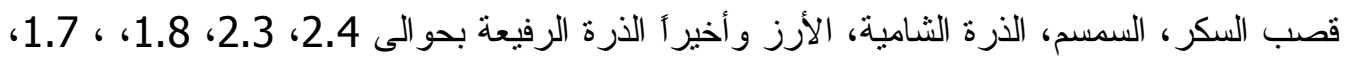

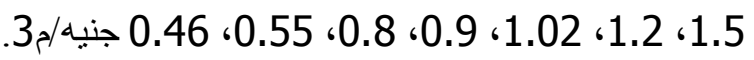
3- عائد الجنيه من تكاليف عملية الرى: 1.5،

من خلال قسمة منوسط الإير اد الكلى للفدان بالجنيه على على منوسط تكاليف الرى ألى أمكن حساب عائد

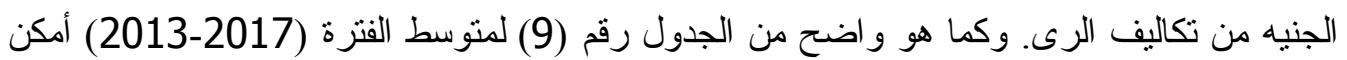
ترنيب تلاكك المجموعة تتازليًا حسب عائد الجنيه من تكاليف الرى، حيث يتصدر محصول البصل المركز الأول بحو الى 57.9 جنيه، يليه الثوم بحوالى 39.7 جنيه، ثم العدس بحو الى 33.9 جنيه، و البرسيم

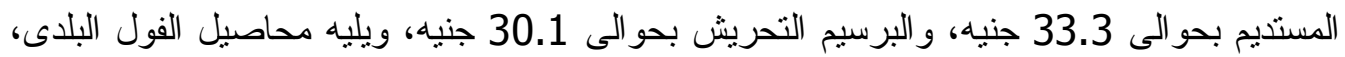

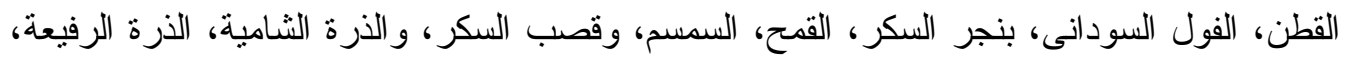
الأرز بحو الى 27.6، 26.4، 26.1، 24.7، 23، 19.3، 18.8، 17.4، 15.5، 13.7 جنيه على

4- 4سبة تكاليف الرى إلى التكاليف المتغيرة:

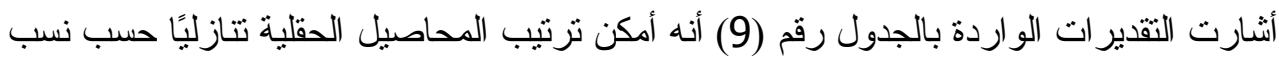
تكاليف الرى إلى التكاليف المتغيرة، حيث يتصدر محصول البرسيم التحريش المرنبة الأولى بنحو

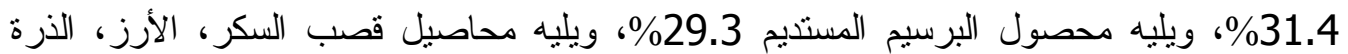

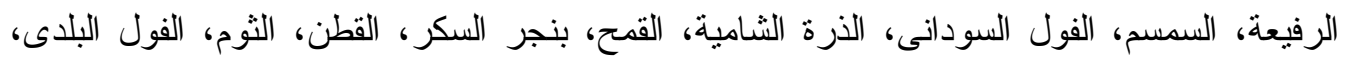

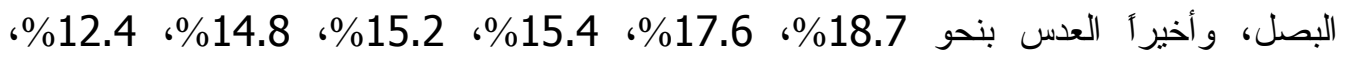

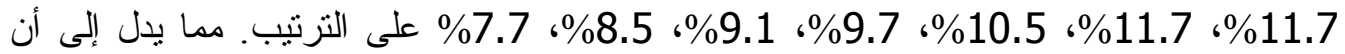

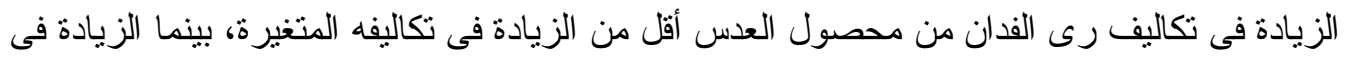
تكاليف رى الفدان لمحصول البرسيم التحريش أكبر من الزيادة فى تكاليفة المتغيرة. 5- نسبة تكاليف الرى إلى التكاليف الكلية: أثنارت الثقديرات الواردة بالجدول رقم (9) أنه أمكن ترتيب المحاصيل الحقلية نتازليًا حسب نسب التبات تكاليف الرى إلى التكاليف الكلية، حيث يتصدر محصولى قصب السكر ، البرسيم التحريش المركزين الأولى والثانى بنحو 11.8\%، 11.4\% ويليه محصول الأرز 11.1\%، ويليه محاصيل الفول

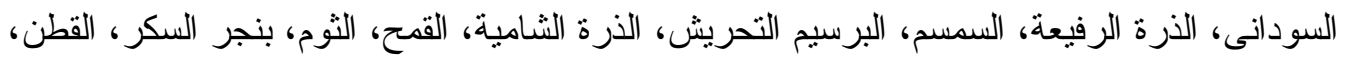

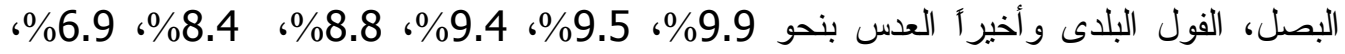

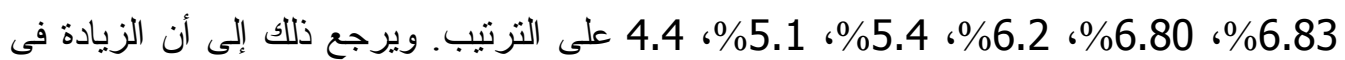

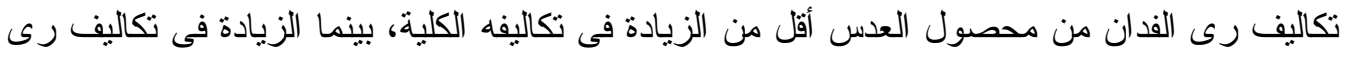
الفدان من محصول قصب السكر و البرسيم التحريش و أيضأ الأرز أكبر من الزيادة فى تكاليفة الكلية. 
جدول (9): المعايير القيمية لكفاعة رى المحاصيل الحقلية المختارة

لمتوسط الفترة (2013-2017)

\begin{tabular}{|c|c|c|c|c|c|c|c|}
\hline 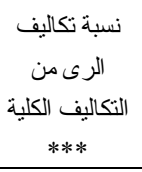 & نسبة تكاليف & عن عن الكاليف الجنيه & التكاليف الكلية & 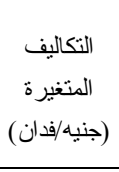 & تكاليف الرى للفان & متوسط الإير اد & \\
\hline 6.85 & 11.7 & 23 & 6410 & 3742.6 & 2.439 & 10082 & القمح \\
\hline 5.1 & 9.1 & 27.6 & 5977.8 & 3362 & 4.304 & 8387 & الفول البلدى \\
\hline 4.4 & 7.7 & 33.9 & 5386 & 3065 & 236 & 7991.8 & العدس \\
\hline 5.4 & 8.5 & 57.9 & 5675 & 3566 & 304 & 17569 & البصل \\
\hline 6.8 & 9.7 & 39.7 & 7392 & 5199.6 & 505 & 20037 & الثوم \\
\hline 11.4 & 29.3 & 33.3 & 4227.4 & 1643 & 482 & 16031 & البستيميم \\
\hline 8.8 & 31.4 & 30.1 & 3007.6 & 849 & 266.2 & 8015.6 & التحريش \\
\hline 6.8 & 11.7 & 24.7 & 5765 & 3357.6 & 391.8 & 9679.8 & بنجر السكر \\
\hline 6.2 & 10.5 & 26.4 & 7656 & 4486.5 & 471 & 12411 & القطن \\
\hline 11.1 & 17.6 & 13.7 & 5821 & 3677.8 & 647 & 8892 & الأرز \\
\hline 8.4 & 12.4 & 17.4 & 5392 & 3660 & 452 & 7847.5 & الذرة الثشامية \\
\hline 11.8 & 18.7 & 18.8 & 9592 & 6060.5 & 1135 & 21345 & قصب السكر \\
\hline 9.5 & 15.4 & 15.5 & 3768 & 2315 & 357.3 & 5534 & الذرة الرفيعة \\
\hline 9.9 & 14.8 & 26.1 & 4934.5 & 3314 & 490.5 & 12789 & الفول السودانى \\
\hline 9.4 & 15.2 & 19.3 & 3900 & 2410 & 365.5 & 7040.8 & السمسم \\
\hline
\end{tabular}

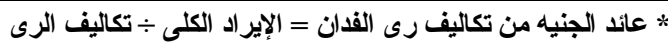

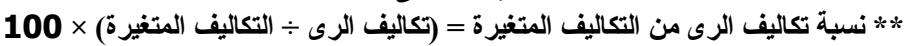

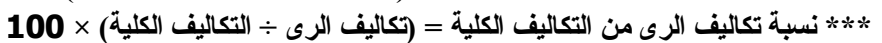

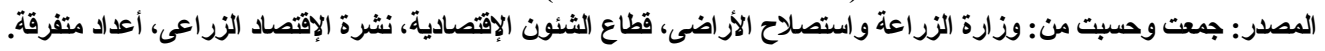
تقدير ات صافى عائد القدان ووحدة المياه فى إطار أهم أنماط التراكيب المحصولية فى مصنى الأنى

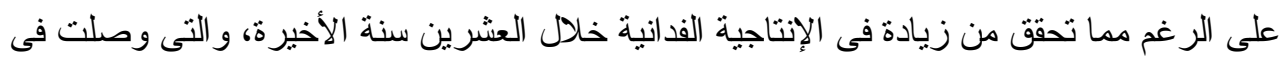

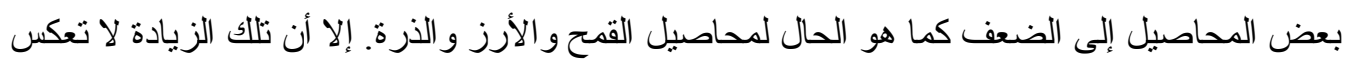

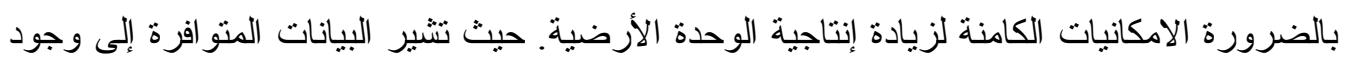

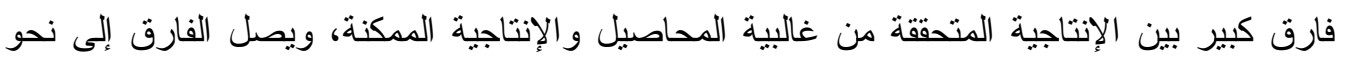

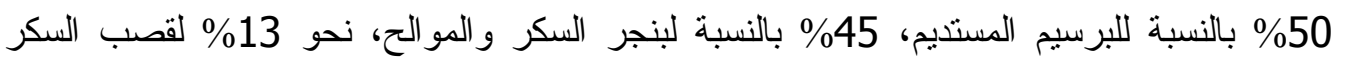

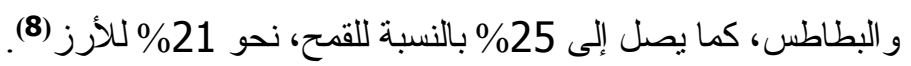

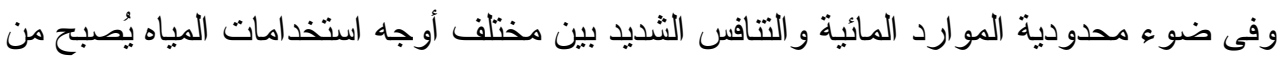

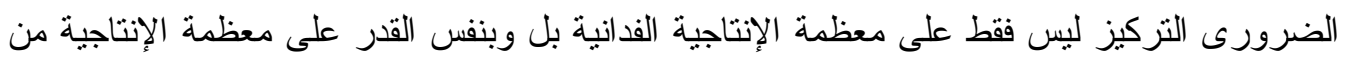

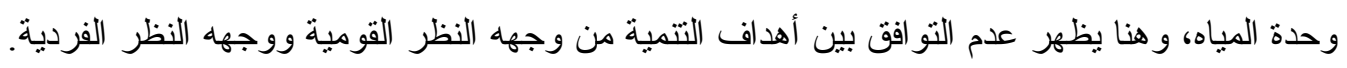

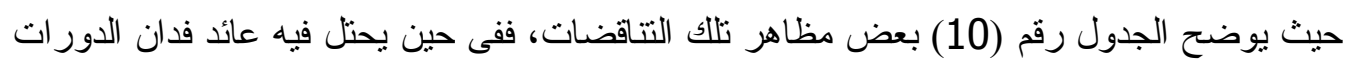

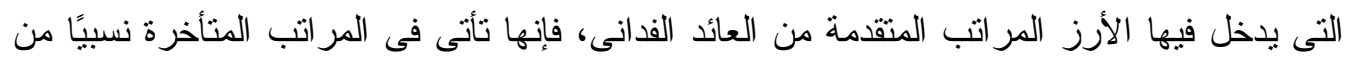

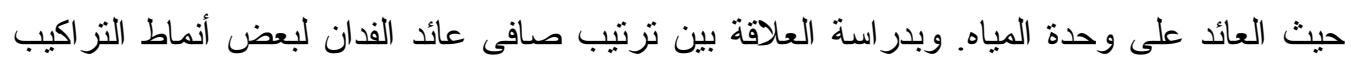

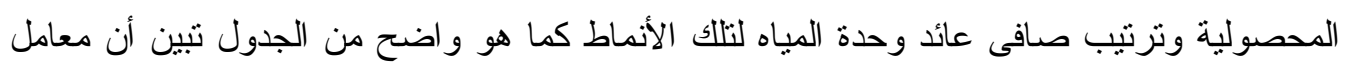

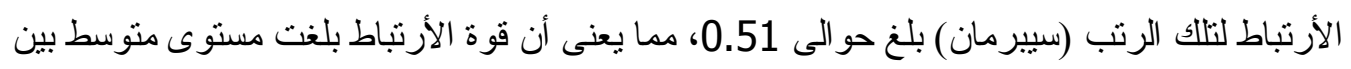


جدول رقم (10): تقدير ات صافى عائد الفدان ووحدة المياه فى إطار أهم أنماط التراكيب المحصولية فى مصر لمتوسط الفترة (2013-2017)

\begin{tabular}{|c|c|c|c|c|}
\hline التزتيب & 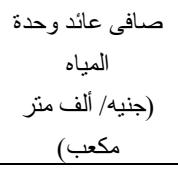 & التزتيب & $\begin{array}{c}\text { صافى عائد الفدان } \\
\text { (جنيه) }\end{array}$ & الدور ات الزر اعية \\
\hline 1 & 6830 & 4 & 11220 & برسيم تحريش/ قطن \\
\hline 6 & 2567 & 8 & 6187 & ق قمح/ ذرة \\
\hline 8 & 2350 & 6 & 68012 & قمح/ أرز \\
\hline 3 & 4842 & 3 & 14259 & بر سيح مستديم/ ذرة \\
\hline 4 & 4625 & 1 & 14874 & برسيم مستديم/ أرز \\
\hline 7 & 2426 & 7 & 6370 & بنجر السكر / ذرة \\
\hline 2 & 6340 & 2 & 14642 & برسيم مستديم/فول الصويا \\
\hline 9 & 2264 & 9 & 5473 & قمح/ ذرة رفيعة \\
\hline 5 & 3182 & 5 & 10126 & بنجر السكر / قطن \\
\hline
\end{tabular}

المصدر : جمعت وحسبت من: وزارة الزراعة و استصلاح الأراضى، قطاع الثشئون الإقتصادية، نشرة الإقتصاد الزراعى، أعداد متفرقة. 


\section{(الملحق \\ جدول رقم (1) المقتن المائى للفدان لبعض المحاصيل الحقلية طبقًا لمناطق (الجمهورية لمتوسط الفترة (2013- 2017)}

(ن)

\begin{tabular}{|c|c|c|c|c|}
\hline المتوسط العام للفدان & مصر العليا & مصر الوسطى & وجه بحرى & محاصيل الأقاليم \\
\hline 2074 & 2783 & 2117 & 1855 & القمح \\
\hline 1739 & 2516 & 1864 & 1632 & الفول البلدى \\
\hline 1105 & 1416 & 1129 & 958.6 & العدس \\
\hline 1929 & 2620 & 2011 & 1809 & البصل \\
\hline 2021 & 2620 & 2011 & 1809 & الثثم \\
\hline 2897 & 4073 & 3107 & 2609 & البرسيم المستديم \\
\hline 943.6 & 1299 & 1137 & 880.6 & البرسيم التحريش \\
\hline 2359 & 3458 & 2644 & 2261 & بنجر السكر \\
\hline 4080 & 5647 & 4599 & 4029 & القطن \\
\hline 5579 & 0 & 6120 & 5578 & الأرز \\
\hline 3200 & 3988 & 3246 & 3051 & الذرة الثشامية \\
\hline 11041 & 11401 & 9035 & 7562 & قصب السكر \\
\hline 3753 & 4063 & 3293 & 3082 & الذرة الرفيعة \\
\hline 3169 & 4181 & 3406 & 2977 & الفول السودانى \\
\hline 3330 & 4215 & 3432 & 3003 & السمسم \\
\hline
\end{tabular}

المصدر: الجهاز المركزى للتعبئة العامة والاحصاء، النشرة السنوية لاحصات الرى والموارد المائية، أعاد مختلفة.

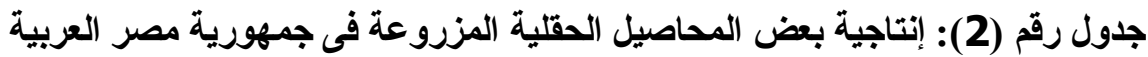

لمتوسط الفترة (2013-2017)

(طن

\begin{tabular}{|c|c|c|c|c|}
\hline المنوسط العام للفدان & مصر العليا & مصر الوسطى & وجه بحرى & المحاصبل \\
\hline 2.79 & 2.74 & 2.87 & 2.85 & القمح \\
\hline 1.45 & 1.20 & 1.11 & 1.36 & الفول البلدى \\
\hline 0.86 & 0.77 & 0.00 & 0.94 & العدس \\
\hline 14.89 & 17.13 & 12.82 & 15.17 & البصل \\
\hline 9.31 & 10.53 & 9.77 & 7.29 & الثوم \\
\hline 30.23 & 30.29 & 25.39 & 30.49 & البرسيم المستديم \\
\hline 12.31 & 16.71 & 9.76 & 12.48 & البرسيم التحريش \\
\hline 21.18 & 29.42 & 23.59 & 20.67 & بنجر السكر \\
\hline 0.76 & 0.86 & 0.79 & 0.76 & القطن \\
\hline 3.94 & 0.91 & 3.63 & 3.74 & الأرز \\
\hline 3.26 & 2.84 & 3.08 & 3.53 & الذرة الثامية \\
\hline 47.89 & 48.41 & 44.03 & 36.78 & قصب السكر \\
\hline 2.16 & 2.24 & 1.99 & 0.00 & الذرة الرفيعة \\
\hline 1.41 & 1.45 & 1.42 & 1.47 & الفول السودانى \\
\hline 0.57 & 0.61 & 0.60 & 0.52 & السمسم \\
\hline
\end{tabular}

المصدر: وزارة الزراعة و استصلاح الأر اضى، قطاع الثئون الإقتصادية، نشرة الإقتصاد الزراعى، أعداد متفرقة. 


\section{التوصيات}

1- التوسع فى زر اعة المحاصيل الأكثر كفاءة فى استخدام مياه الرى و التى تحقق أعلى عائد لوحدة مياه الرى بما يتماثىى مع الظروف الإقتصادية المصرية. 2- تقليل الفو اقد المائية ورفع كفاءة نقل وتوزيع المياه، وتغطية التزع ع الرئيسية و استخدام المو اسبر لتقليل الفاقد بالبخر من المياه.

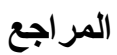

(1) أكرم محمد محمود حماد، "إقتصاديات استخدام الموارد المائية فى الزر اعة المصرية"، رسالة

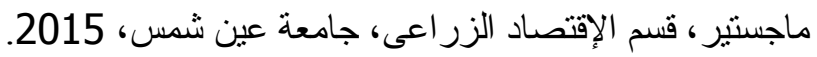

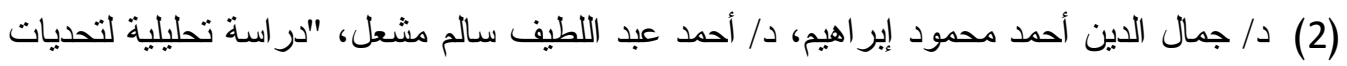

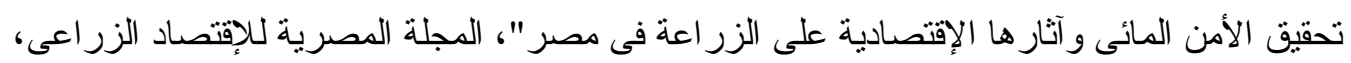

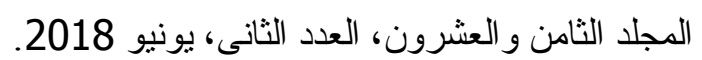

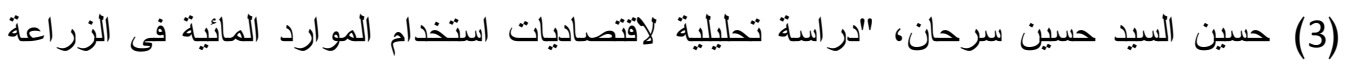

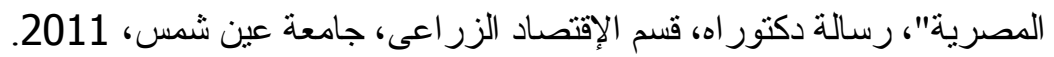

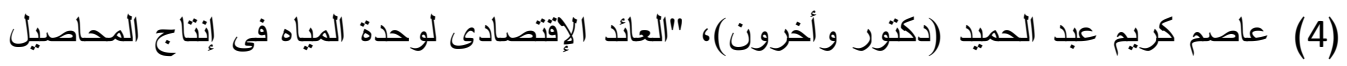

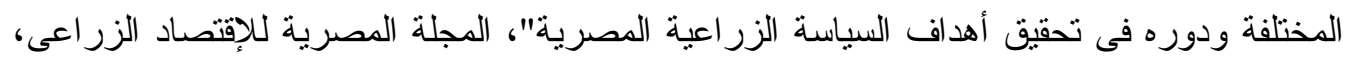

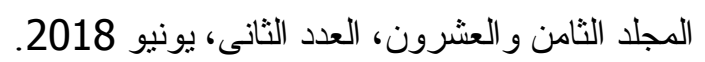
(5) محمد مدحت مصطفى (دكتور )، "إقتصاديات المو ارد المائية (رؤية شاملة لإدارة المياه)"، مكتبة

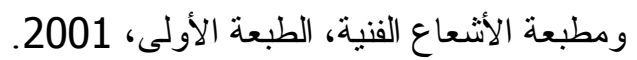
(6) الجهاز المركزى للتعبئة العامة و الاحصاء، النشرة السنوية لاحصات الاعلة الرى و المو ارد المائية، أعداد مختلفة. (7) الحهاز المركزى والاحصاء، الموارد المائية ونرشيد استخدامها فى مصر، موقع إنترنت: www.capmas.gov.eg (8) وزر اة الزر اعة و استصلاح الأر اضى، "اسنز اتيجية التتمية الزر اعية المستدامة حتى عام 2030"،

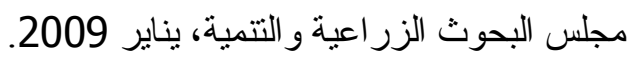
(9) وزارة الزر اعة واستصلاح الأر اضى، قطاع الشئون الإقتصادية، نشرة الإقتصاد الزر اعى، أعداد 